\title{
Dust storms come to Central and Southwestern China, too: implications from a major dust event in Chongqing
}

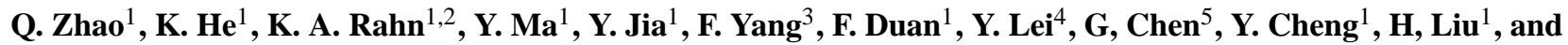 \\ S. Wang ${ }^{1}$ \\ ${ }^{1}$ State Key Joint Laboratory of Environment Simulation and Pollution Control, Department of Environmental Science and \\ Engineering, Tsinghua University, Beijing, China \\ ${ }^{2}$ Graduate School of Oceanography, University of Rhode Island, Narragansett, Rhode Island, USA \\ ${ }^{3}$ School of Earth Science, Graduate University of Chinese Academy of Sciences, Beijing, China \\ ${ }^{4}$ School of Engineering and Applied Science, Harvard University, Cambridge, Massachusetts, USA \\ ${ }^{5}$ Chongqing Environmental Protection Bureau, Chongqing, China
}

Received: 20 June 2009 - Published in Atmos. Chem. Phys. Discuss.: 15 December 2009

Revised: 14 February 2010 - Accepted: 8 March 2010 - Published: 18 March 2010

\begin{abstract}
Dust storms from major Asian sources are usually carried by northwesterly or westerly winds over Northern and Southeastern China to the Pacific Ocean. These pathways leave Central and Southwestern China nearly free of incursions. But a strong dust event on 5-6 May 2005 was captured in a 15-month series of weekly filter samples of $\mathrm{PM}_{2.5}$ at three sites in Chongqing. It illustrated that desert dust can be transported to this region, and sometimes strongly. Annual $\mathrm{PM}_{2.5}$ and dust were similar at the three sites, but higher than in simultaneous samples in Beijing. High correlations of dust concentrations were found between the cities during spring, indicating that Asian dust affects a broader swath of China than is often realized. During the event, the concentrations of mineral dust were high at all sites $\left(20-30 \mu \mathrm{g} \mathrm{m}^{-3} ; 15 \%-20 \%\right.$ of $\mathrm{PM}_{2.5}$ in Chongqing, and $15 \mu \mathrm{g} \mathrm{m}^{-3} ; 20 \%-30 \%$ of $\mathrm{PM}_{2.5}$ in Beijing), and were part of a broader spring maximum. The proportions of crustal elements and pollution-derived components such as $\mathrm{Pb}, \mathrm{SO}_{4}^{2-}$, and organic carbon indicated that the sources for this dust differed from Beijing. The dust was considerably enriched in $\mathrm{Ca}$ and $\mathrm{Mg}$, characteristic of western deserts, whereas Beijing's dust had the lower $\mathrm{Ca}$ and $\mathrm{Mg}$ of eastern deserts. This observation agrees with synoptic patterns and backtrajectories. Driven by a cold air outbreak from the northwest, dust from the western Gobi Desert was transported at lower altitudes ( $<2 \mathrm{~km}$ above ground level), while dust from the Takla Makan Desert was transported to Chongqing at
\end{abstract}

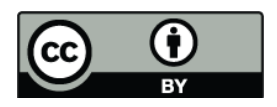

Correspondence to: $\mathrm{K}$. He (hekb@tsinghua.edu.cn) higher altitudes. Desert dust can also be important to wide areas of China during the cold season, since almost all the weekly dust peaks in the two cities coincided with extensive dust emissions in source regions. These findings collectively suggest that the amount Asian-dust in China has been underestimated both spatially and temporally, and that transported alkaline dust can even be mitigating the effects of acidic deposition in Southern China.

\section{Introduction}

Arid regions of Southern Mongolia and Northwestern China are among the main contributors to global dust emission, via periodic Asian Dust Events (ADEs). Mobilized by high wind speeds and frontal lifting during cold air outbreaks, desert dust is easily transported over long distances by the prevailing westerlies (Husar et al., 2001; Sun et al., 2001), and affects visibility, air quality, and human health. The dust can also influence the radiative budget directly and indirectly, with a magnitude similar to that of greenhouse gases (IPCC, 2001).

During spring, when most dust is emitted, ADEs have been found not only in midlatitude China (He et al., 2001; Liu et al., 2002a; Zhang et al., 2001; Zhang et al., 2003a; Zhang et al., 2003b; Guo et al., 2004), Korea (Kim et al., 2006), and Japan (Fu et al., 2004), but also as far away as North America (Husar et al., 2001;VanCuren and Cahill, 2002), the Arctic (Bory et al., 2002), and the tropical Taiwan (Cheng et al., 2005), Hong Kong (Wai and Tanner, 2005), and the mid-Pacific (Holmes and Zoller, 1996). But the influence

Published by Copernicus Publications on behalf of the European Geosciences Union. 
of Asian dust is still not clear over Central and Southwestern China, where ambient aerosol has been less studied (Chan and Yao, 2008; Fang et al., 2009). A recent field program (Zhang et al., 2008) found high dust loading in several cities of this region, but it was attributed to local human activity, based on the historical assumption that this region is nearly free of Asian dust incursions. Since alkaline dust helps neutralize the acidic aerosols and their precursors, it is important to understand the deposition mechanism of cations and how they could affect the chemistry of particulate matter (PM) in this region (Larssen et al., 2000, 2001), which has experienced acid rain for decades.

Asian deserts emit dust year-round (Laurent et al., 2005). The dust can also affect distant locations in seasons other than spring, especially when resuspension in downwind regions is restrained by climatic conditions such as abundant precipitation and low wind speed (Liu et al., 2008). Fine Asian dust has been found to be a regular component of the troposphere over the eastern Pacific and western North America in all seasons (VanCuren and Cahill, 2002). In China, however, previous characterizations of Asian dust have been limited to short-term campaigns or semicontinuous routine sampling (say once each few days), and the effect of transported crustal species during non-ADEs remains an open question for most megacities of China (Chan and Yao, 2008).

On 5-6 May 2005, a rare ADE was reported in Chongqing, in the middle of Central-Southwestern China (Chongqing Times, 2005), but was only noticed by local media. By chance, this event was captured during a 15 months of continuous sampling of $\mathrm{PM}_{2.5}$ (aerodynamic diameter $<2.5 \mu \mathrm{m}$ ) from January 2005 to May 2006, and has provided a first opportunity to evaluate the influence of Asian desert dust over this region. Here the chemical composition and transport of the fine dust for this event are investigated relative to the dust characteristics over the whole campaign. $\mathrm{PM}_{2.5}$ collected in parallel in Beijing is compared to the data for Chongqing to get an idea of regional differences. At the end is discussed the possibility of widespread underestimation of ADEs in China, which is crucial to national ambient air-quality standards and wet/dry deposition.

\section{Experimental}

\subsection{Sampling sites}

$\mathrm{PM}_{2.5}$ samples were taken simultaneously in Chongqing and Beijing. Chongqing lies on the Yangtze River in mountainous Southwestern China, near the eastern border of the Sichuan Basin and the western border of Central China. It became the fourth municipality centrally directed in 1997 , and contains a population of over 28 million, almost twice of that of Beijing, with most people living in rural areas (Chongqing Municipal Bureau of Statistics, 2008). For to-

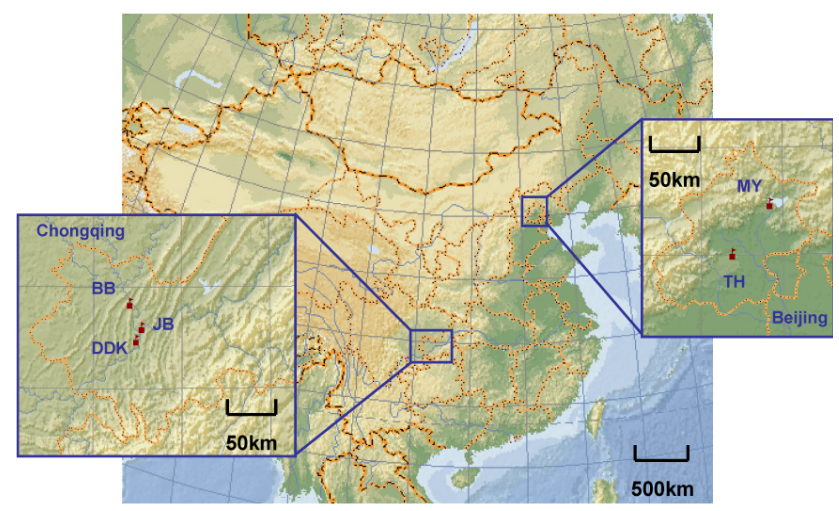

Fig. 1. Sampling sites in Chongqing (Jiangbei(JB), Dadukou (DDK) and Beibei (BB)) and Beijing (Tsinghua (TH) and Miyun (MY)), China. The topography map is derived from the Microsoft Encarta 2009@ 1993-2008.

pographic reasons, Chongqing has some of the lowest wind speeds in China (annual averages of $0.9-1.6 \mathrm{~m} \mathrm{~s}^{-1}$ from 1979 to 2007; Chongqing Municipal Bureau of Statistics, 2008), which favors the accumulation of pollutants.

Three sampling sites were selected in Chongqing: urban residential, urban industrial, and rural background (Fig. 1). The residential site was on the roof of the Chongqing Monitoring Center, in the Jiangbei District (JB, $29^{\circ} 34^{\prime} \mathrm{N}$, $106^{\circ} 32^{\prime} \mathrm{E}$ ), close to restaurants and busy roads. The industrial site was on the roof of the governmental house of the Dadukou District (DDK, $29^{\circ} 29^{\prime} \mathrm{N}, 106^{\circ} 29^{\prime} \mathrm{E}$ ), near a power plant and steel smelter with annual production over 15 million tons. The rural site was near the Jinyun Mountain in the Beibei District (BB, $\left.29^{\circ} 50^{\prime} \mathrm{N}, 106^{\circ} 25^{\prime} \mathrm{E}\right), 40 \mathrm{~km}$ northwest of the city center with no point sources nearby.

Beijing is located near the northern border of the Great North China Plain, and has a population of 16 million (Beijing Municipal Bureau of Statistics, 2008). It is $400 \mathrm{~km}$ southeast of the Gobi Desert, the main dust source for Northern China. Under the prevailing north and northwest winds of spring, Beijing regularly receives transported dust. Urban and rural sites were selected, $70 \mathrm{~km}$ apart (Fig. 1). The urban site was located inside Tsinghua University $\left(\mathrm{TH}, 40^{\circ} 19^{\prime} \mathrm{N}\right.$, $116^{\circ} 19^{\prime} \mathrm{E}$ ). The rural site was near the Miyun Reservoir (MY, $40^{\circ} 29^{\prime} \mathrm{N}, 116^{\circ} 47^{\prime} \mathrm{E}$ ), northeast of the city center. Both sites have been described previously (He et al., 2001; Jia et al., 2008).

\subsection{Sampling and analysis}

Weekly $\mathrm{PM}_{2.5}$ samples were collected at the five sites with a three-channel low-flow sampler (Aerosol Dynamics Inc., Berkeley, CA). Details have been reported previously (He et al., 2001). The sampler had three parallel channels, each with a flow rate of $0.4 \mathrm{~L} / \mathrm{min}$. In the first channel, acidic gases were removed by a glass denuder, and the particles were 
collected on a Teflon filter for measuring water-soluble ions. A nylon after-filter collected any nitric acid volatilized from the first filter. In the second channel, particles were collected on a single Teflon filter for measuring mass and elements. In the third channel, a single quartz-fiber filter (prefired at $900^{\circ}$ for $5 \mathrm{~h}$ to remove residual carbon) was used to measure carbonaceous components. The filters were run continuously for a week, and changed every Friday. From January 2005 into May 2006, 180 and 106 samples were collected in Chongqing and Beijing, respectively.

Mass concentrations were obtained by weighing on an analytical balance (Mettler Toledo AG285), after stabilizing under constant temperature $\left(20^{\circ} \mathrm{C} \pm 5^{\circ} \mathrm{C}\right)$ and humidity $(40 \% \pm 5 \%)$. Using the EPA standard method, 23 elements (Al, $\mathrm{Na}, \mathrm{Cl}, \mathrm{Mg}, \mathrm{Si}, \mathrm{S}, \mathrm{K}, \mathrm{Ca}, \mathrm{Ti}, \mathrm{V}, \mathrm{Cr}, \mathrm{Mn}, \mathrm{Fe}, \mathrm{Ni}, \mathrm{Cu}, \mathrm{Zn}$, $\mathrm{As}, \mathrm{Se}, \mathrm{Br}, \mathrm{Sr}, \mathrm{Cd}, \mathrm{Ba}, \mathrm{Pb}$ ) were measured by XRF (model RIX3000, details provided in $\mathrm{He}$ et al., 2001). Nine main ions $\left(\mathrm{K}^{+}, \mathrm{Ca}^{2+}, \mathrm{Na}^{+}, \mathrm{Mg}^{2+}, \mathrm{NH}_{4}^{+}, \mathrm{SO}_{4}^{2-}, \mathrm{NO}_{3}^{-}, \mathrm{Cl}^{-}\right)$were measured by ion chromatography (Dionex 600, details in Wang et al., 2005b). Organic carbon (OC) and elemental carbon (EC) were measured by the thermal/optical reflectance method, as described by $\mathrm{He}$ et al. (2001).

At the JB site in Chongqing, hourly $\mathrm{PM}_{10}$ mass concentration in spring of 2005 was also measured by a ThermoElectron TEOM (obtained from Chongqing Environmental Protection Bureau).

\subsection{Meteorological data and simulations}

Hourly meteorological data for Chongqing and Beijing were obtained on-line from Weather Underground (http:// www.wunderground.com), and included temperature, dewpoint, wind speed, visibility and precipitation. Surface synoptic patterns, including mean sea-level pressure, and geopotential height, were generated from the NOAA READY archived meteorology data (http://www.arl.noaa. gov/READYamet.php).

To characterize the transport pathways of the dust, 3-D back-trajectories were calculated with the NOAA Hybrid Single-Particle Lagrangian Integrated Trajectory (HYSPLIT) model via the website www.arl.noaa.gov/ready/hysplit4.html. Model results provided by the U.S. Naval Research Laboratory Aerosol Analysis and Prediction System (NAAPS) were used to simulate the temporal and spatial distribution of dust over China (http://www.nrlmry.navy.mil/flambe-bin/aerosol/ display_directory_aer2?DIR=/web/aerosol/public_html/ globaer/ops_01/mongolia/). This model simulates fine dust $(<5 \mu \mathrm{m})$ at constrained surface level, and presents its output every six hours (UTC 00:00, 06:00, 12:00, and 18:00).

\section{General characteristics of $\mathbf{P M}_{2.5}$ and mineral dust at Chongqing}

\section{1 $\mathbf{P M}_{2.5}$ concentration}

Annual concentrations of $\mathrm{PM}_{2.5}$ from March 2005 into February 2006 were about $130 \mu \mathrm{g} \mathrm{m}^{-3}$ at the three sites in Chongqing (Table 1).

Although there is no national air-quality standard for $\mathrm{PM}_{2.5}$ in China, the concentrations exceeded the Chinese annual standard II for $\mathrm{PM}_{10}\left(100 \mu \mathrm{g} \mathrm{m}^{-3}\right)$ by $30 \%$. Our result is 20\% higher than previously reported for 1995 in Chongqing, $113 \mu \mathrm{g} \mathrm{m}^{-3}$ urban and $97 \mu \mathrm{g} \mathrm{m}^{-3}$ rural (Wei et al., 1999). Although this difference may be attributable to different ways of measuring $\mathrm{PM}_{2.5}$, the similar urban and rural values show that fine aerosol was distributed nearly homogeneously over Chongqing, and that the additional 10 years of urbanization may have elevated the $\mathrm{PM}_{2.5}$ over the area. Our annual $\mathrm{PM}_{2.5}$ in Chongqing also exceeded the reported $\mathrm{PM}_{10}$ for $2005\left(120 \mu \mathrm{g} \mathrm{m}^{-3}\right.$, Chongqing Municipal Bureau of Statistics, 2006). This inconsistency could be attributed to the two months' difference in time between the data sets, or to different methods of measuring the aerosol. Chinese national monitoring stations generally use TEOMs, and heat the samples to $50^{\circ} \mathrm{C}$ before analysis, which may underestimate the semivolatile organic and inorganic species in aerosols.

$\mathrm{PM}_{2.5}$ in Beijing was less concentrated than in Chongqing (118 $\mu \mathrm{g} \mathrm{m}^{-3}$ for $\mathrm{TH}, 68 \mu \mathrm{g} \mathrm{m}^{-3}$ for MY). Although missing samples in Beijing during the cold season may have led to an underestimate of its $\mathrm{PM}_{2.5}$, the concentration in Chongqing was still comparable to Beijing's value for 1999$2000\left(127 \mu \mathrm{g} \mathrm{m}^{-3}\right.$, He et al., 2001). Beijing also showed a greater difference between urban and rural areas, as $\mathrm{PM}_{2.5}$ in MY was only $60 \%$ of that at TH.

Concerning the uncertainties of the above comparison, the samples covered $92 \%, 94 \%, 83 \%, 85 \%$ and $80 \%$ of the 52 weeks from March 2005 to February 2006 at JB, DDK, BB, TH and MY, respectively. Thus, their averages should reasonably represent the concentrations at each site. The plausibility of this approach can be shown by a worst-case example for MY, where $20 \%$ of the samples were missing. Even if the average of the $20 \%$ unsampled weeks was $50 \%$ higher than the sampled weeks (highly unlikely), it would only increase the average by $10 \%$. A more-reasonable difference of $5 \%$ would change the average by only $1 \%$.

\subsection{Reconstructing the concentration of dust}

The strong dust event of 5-6 May 2005 in Chongqing made us wonder how much unrecognized desert dust might be present on other occasions. Answering this question required two steps: reconstructing the concentrations of total dust from our elemental concentrations, and apportioning it between local and distant sources. This section deals with the 
Table 1. Annual concentrations of $\mathrm{PM}_{2.5}$ and major chemical species in Chongqing(JB, DDK and BB) and Beijing (TH and MY) from March 2005 to February 2006.

\begin{tabular}{|c|c|c|c|c|c|}
\hline \multirow{2}{*}{$\begin{array}{l}\text { City } \\
\text { Sampling site }\end{array}$} & \multicolumn{3}{|c|}{ Chongqing } & \multicolumn{2}{|c|}{ Beijing } \\
\hline & JB & DDK & $\mathrm{BB}$ & $\mathrm{TH}$ & MY \\
\hline $\mathrm{PM}_{2.5} / \mathrm{\mu g} \mathrm{m}^{-3}$ & $128.99 \pm 42.59$ & $133.70 \pm 44.13$ & $126.10 \pm 43.40$ & $118.50 \pm 40.64$ & $68.44 \pm 24.73$ \\
\hline Number of samples & 48 & 49 & 43 & 44 & 42 \\
\hline \multicolumn{6}{|l|}{ Crustal elements/ $\mu \mathrm{g} \mathrm{m}^{-3}$} \\
\hline $\mathrm{K}$ & $4.29 \pm 1.65$ & $4.68 \pm 1.64$ & $5.02 \pm 2.01$ & $3.52 \pm 1.77$ & $2.49 \pm 1.06$ \\
\hline $\mathrm{Si}$ & $2.20 \pm 1.38$ & $2.23 \pm 1.13$ & $1.76 \pm 0.96$ & $1.79 \pm 0.80$ & $1.23 \pm 0.70$ \\
\hline $\mathrm{Fe}$ & $1.58 \pm 0.82$ & $2.10 \pm 1.14$ & $0.86 \pm 0.43$ & $1.13 \pm 0.41$ & $0.71 \pm 0.30$ \\
\hline $\mathrm{Ca}$ & $1.12 \pm 0.71$ & $1.17 \pm 0.59$ & $0.77 \pm 0.45$ & $0.90 \pm 0.39$ & $0.51 \pm 0.26$ \\
\hline $\mathrm{Al}$ & $0.80 \pm 0.56$ & $0.81 \pm 0.45$ & $0.64 \pm 0.43$ & $0.79 \pm 0.32$ & $0.51 \pm 0.28$ \\
\hline $\mathrm{Na}$ & $0.67 \pm 0.27$ & $0.65 \pm 0.20$ & $0.51 \pm 0.18$ & $0.61 \pm 0.28$ & $0.32 \pm 0.12$ \\
\hline $\mathrm{Mg}$ & $0.28 \pm 0.19$ & $0.31 \pm 0.17$ & $0.21 \pm 0.14$ & $0.29 \pm 0.12$ & $0.17 \pm 0.09$ \\
\hline $\mathrm{Mn}$ & $0.14 \pm 0.07$ & $0.18 \pm 0.08$ & $0.12 \pm 0.05$ & $0.09 \pm 0.03$ & $0.06 \pm 0.03$ \\
\hline $\mathrm{Ti}$ & $0.16 \pm 0.18$ & $0.15 \pm 0.12$ & $0.07 \pm 0.04$ & $0.08 \pm 0.03$ & $0.06 \pm 0.03$ \\
\hline \multicolumn{6}{|c|}{ Pollution-derived components/ $\mu \mathrm{g} \mathrm{m}^{-3}$} \\
\hline $\mathrm{Pb}$ & $0.32 \pm 0.12$ & $0.35 \pm 0.14$ & $0.29 \pm 0.12$ & $0.24 \pm 0.12$ & $0.15 \pm 0.08$ \\
\hline $\mathrm{SO}_{4}^{2-}$ & $25.57 \pm 9.03$ & $23.42 \pm 8.27$ & $23.76 \pm 8.61$ & $15.77 \pm 10.34$ & $12.71 \pm 9.17$ \\
\hline $\mathrm{OC}^{4}$ & $30.13 \pm 10.96$ & $33.71 \pm 10.47$ & $29.43 \pm 9.29$ & $24.54 \pm 12.01$ & $15.62 \pm 5.95$ \\
\hline Mineral components $/ \mu \mathrm{g} \mathrm{m}^{-3}$ & $9.65 \pm 6.21$ & $9.87 \pm 5.08$ & $7.53 \pm 4.35$ & $8.45 \pm 3.38$ & $5.50 \pm 2.95$ \\
\hline Mineral contribution/\% & $7.54 \pm 3.97$ & $7.33 \pm 3.75$ & $6.15 \pm 3.27$ & $7.62 \pm 4.32$ & $8.23 \pm 4.71$ \\
\hline
\end{tabular}

$\pm:$ Standard Deviation

reconstruction; the apportionment will be considered in an accompanying paper.

The reconstruction contained three steps: (1) determine which of the "crustal" elements exist in crustal proportions, and sum the concentrations of their oxides (because the crustal indicators exist as oxides in the crust); (2) determine which of the "crustal" elements in the fine aerosol contain significant pollution components, and generate the crustal concentrations of their oxides from known crustal ratios to $\mathrm{Al}$; (3) sum the results of steps (1) and (2). Details follow.

Our measurements provided concentrations for nine of the most abundant crustal elements: $\mathrm{Al}, \mathrm{Si}, \mathrm{Fe}, \mathrm{Ca}$, Mg, K, Na, Ti and Mn (Taylor and McLennan, 1995). Their average concentrations for March 2005 to February 2006 followed nearly the same ranking at the five sites: $\mathrm{K}>\mathrm{Si}>\mathrm{Fe}>\mathrm{Ca}>\mathrm{Al}>\mathrm{Na}>\mathrm{Mg}>\mathrm{Mn} \approx \mathrm{Ti}$ (Table 1). This sequence, however, differed from the typical crustal sequence, $\mathrm{Si}>\mathrm{Al}>\mathrm{Fe}>\mathrm{Ca}>\mathrm{Na}>\mathrm{Mg}>\mathrm{K}>\mathrm{Ti}>\mathrm{Mn}$ (Taylor and McLennan, 1995). Thus, some of the elements contained significant components from pollution sources, which is often the case in fine aerosol. (Note in passing that the concentrations were all higher in Chongqing than in Beijing, in spite of Beijing's reputation as a dust city.)

The two sequences show that the aerosol was enriched in $\mathrm{K}, \mathrm{Fe}, \mathrm{Ca}$, and $\mathrm{Na}$ relative to the crustal sequence. Whether any of these enrichments were significant can be shown by quantifying them by means of the aerosol-crustal enrichment factor:

$E F_{i}=\frac{\left(C_{i} / C_{r}\right)_{A}}{\left(C_{i} / C_{r}\right)_{S}}$

Here $A$ and $S$ refer to aerosol and bulk soil, respectively, and $C_{i}$ and $C_{r}$ to the concentrations of the ith element and reference element Al (Uematsu et al., 1983; Zhang et al., 2003b). The crustal profile is taken from the values of average crustal rock (Taylor and McLennan, 1995), whose elemental ratios to $\mathrm{Al}$ are close to those in Chinese soils (Yuan et al., 2008).

Elements with $E F<5$ can be considered mainly soilderived (Gao et al., 2002). Applying this criterion to the enrichment factors for Chongqing shown in Fig. 2, the true crustal elements would be $\mathrm{Si}, \mathrm{Al}, \mathrm{Na}$, and $\mathrm{Mg}$, with $\mathrm{Ti}, \mathrm{Ca}$, and Fe being of mixed origin and $\mathrm{K}$ and $\mathrm{Mn}$ being strongly pollution-derived. The clearest crustal elements were $\mathrm{Si}, \mathrm{Al}$, and $\mathrm{Mg}$.

The enrichments of the other elements need to be considered more carefully. The modest enrichment of $\mathrm{Na}$ (2.6) may be an underestimate caused by its higher concentrations in the reference rock than in the actual desert soils. Thus it may be more affected by pollution than its EF suggests, in line with its having the same seasonal variation as the pollutionderived $\mathrm{Pb}$ and $\mathrm{OC}$ (a maximum in the cold season), which differs from the spring maxima of the clearest crustal elements $\mathrm{Al}$ and $\mathrm{Si}$. $\mathrm{Na}$ is also highly enriched in coal flyash 


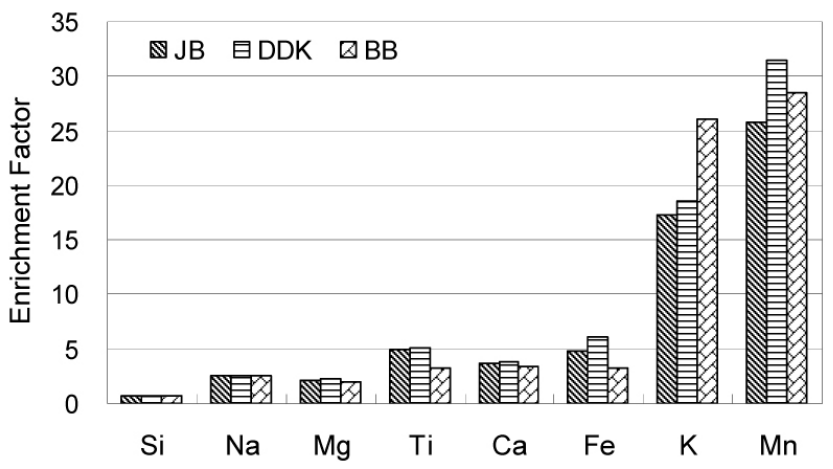

Fig. 2. Enrichment factors of $\mathrm{Si}, \mathrm{Na}, \mathrm{Mg}, \mathrm{Ti}, \mathrm{Ca}, \mathrm{Fe}, \mathrm{K}$ and $\mathrm{Mn}$ in $\mathrm{PM}_{2.5}$ at JB, DDK and BB in Chongqing.

(Guo et al., 2008), which may contribute significant mass to $\mathrm{PM}_{2.5}$ in Chinese cities (Sun et al., 2004). The modest enrichment of $\mathrm{Ca}(3-4)$ was possibly contributed to by construction dust (Zhang and Iwasaka, 1999), but we considered it a crustal element because enrichments of this order can also exist in deserts. The high enrichment of $\mathrm{K}$ seems to be consistent with biomass burning as a major source of aerosols in Chongqing (Cachier and Ducret, 1991; Duan et al., 2004), especially at the rural site, where the EFs were highest. Biomass burning may be a regional source for Southwestern China in general, because that area accounts for $40 \%$ of the China's total consumption of biofuels (National Bureau of Statistics of China, 2007).

Since $\mathrm{Al}, \mathrm{Si}, \mathrm{Ca}$, and $\mathrm{Mg}$ in Chongqing and Beijing were dominated by crustal sources, their oxides $\left(\mathrm{Al}_{2} \mathrm{O}_{3}, \mathrm{SiO}_{2}\right.$, $\mathrm{CaO}$ and $\mathrm{MgO}$ ) were calculated directly from their elemental concentrations (step 1 above). The other mineral oxides $\left(\mathrm{K}_{2} \mathrm{O}, \mathrm{Fe}_{2} \mathrm{O}_{3}, \mathrm{MnO}, \mathrm{Na}_{2} \mathrm{O}, \mathrm{Ti}_{2} \mathrm{O}\right)$ were estimated from their crustal ratios to $\mathrm{Al}$ and the composition of average crustal rock provided by Taylor and McLennan (1995). This was step 2 above. Then the set of nine oxides was summed to give a total concentration of crustal dust (step 3 above).

Like $\mathrm{PM}_{2.5}$, the annual concentrations of dust were higher in Chongqing $\left(8-10 \mu \mathrm{g} \mathrm{m}^{-3}\right)$ than in Beijing $\left(6-8 \mu \mathrm{g} \mathrm{m}^{-3}\right)$ (Table 1). Although the urban sites contributed similar amounts to their $\mathrm{PM}_{2.5}(7.3 \%-7.6 \%)$, the rural site in Beijing contributed more than the rural site in Chongqing $(8.2 \%$ at MY, vs. $6.2 \%$ at BB). This may indicate a more significant overall influence of dust in Northern China because of its dry climate and more-frequent dust incursions. Although mineral dust was only a small fraction of $\mathrm{PM}_{2.5}$ at both cities, it could promote the formation of secondary aerosol by providing significantly larger (up to an order of magnitude) surface area for heterogeneous reactions (Dentener et al., 1996; Usher et al., 2003). Considerable internally mixed submicron Asian dust and hygroscopic sulfate/nitrate have also been observed in recent field observations (Sullivan et al., 2007; Li et al., 2009).

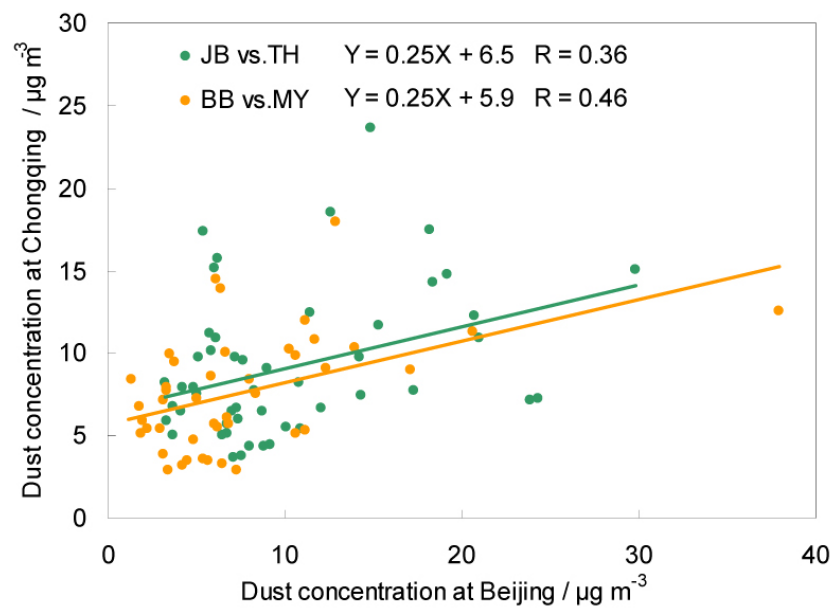

Fig. 3. Scatter-plot comparison of the urban and rural dust concentrations between Chongqing (JB and $\mathrm{BB}$ ) and Beijing (TH and MY).

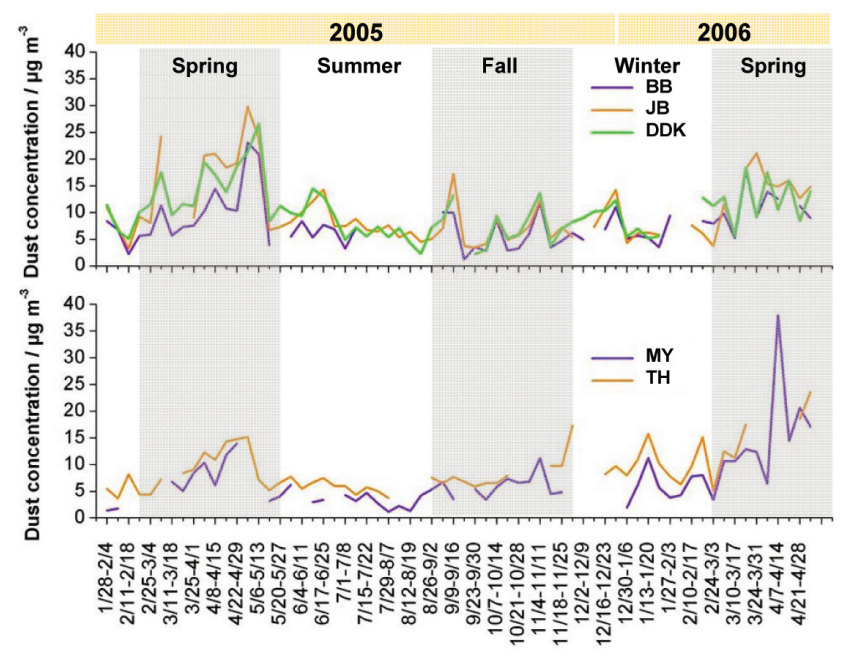

Fig. 4. Seasonal variation of reconstructed dust concentration in $\mathrm{PM}_{2.5}$ in Chongqing and Beijing from Jan. 2005 to May 2006.

The dust was moderately correlated at Chongqing and Beijing (0.36-0.46; shown graphically in Fig. 3). The residential sites JB and TH had the lower value of 0.36 , while the rural sites BB and MY had the higher 0.46. Thus there seems to be some regional factor(s) (probably at least meteorological) controlling the dust on scales up to at least $1500 \mathrm{~km}$.

Dust at Chongqing and Beijing showed the same seasonal trends, with maxima in spring, minima in summer, and intermediate values during fall and winter, all with large fluctuations (Fig. 4). Chongqing had significantly higher dust in spring 2005 than in spring 2006, due to the large ADE of 5-6 May 2005. Because the filters were changed during the ADE (on Friday, 6 May), average concentrations for 29 April6 May and 6-13 May only reached $20-30 \mu \mathrm{g} \mathrm{m}^{-3}(15 \%-$ $20 \%$ of $\mathrm{PM}_{2.5}$ ), which was still the highest level during the 
sampling period. These weeks coincided with the spring maximum of dust at Beijing, which had a similar fraction of $\mathrm{PM}_{2.5}(20 \%)$. But the concentration in Beijing $(15 \mu \mathrm{g} \mathrm{m})^{-3}$ at $\mathrm{TH})$ was only half that of Chongqing $\left(30 \mu \mathrm{g} \mathrm{m}^{-3}\right.$ at JB).

In addition to having similar seasonal trends at Chongqing and Beijing, the dust was also well correlated between the sites during spring. The three sites in Chongqing were strongly correlated with each other (up to 0.88 between JB and $\mathrm{BB}$, for example), as were the sites in Beijing ( 0.95 for $\mathrm{TH}$ and MY). The concentrations between the cities were better correlated ( 0.62 and for JB and TH) than between the rural sites ( 0.55 for $\mathrm{BB}$ and MY). Reflecting the regional nature of Asian dust, correlated dust concentrations in spring have also been found in many multisite regional studies in East Asia and the North Pacific (Uematsu, 1983; Arimoto, 1996; Mori et al., 2002; Zhang et al., 2003b; Cohen et al., 2004; Wang et al., 2007).

After the spring outbreak of dust, the summer monsoon from the tropics brought abundant precipitation and led to the minimum in July and August. Later, dry air masses from the northwest increasingly entered the mainland of China, and resulted in the higher dust of fall and winter. Asian dust may also have played an important role during these periods even without any ADEs being reported, as discussed in Sect. 5 .

\section{The major Asian Dust Event in Chongqing}

\section{1 $\mathrm{PM}_{10}$ concentration and meteorological factors}

The ADE in Chongqing during 5-6 May 2005 provided a unique opportunity to better understand how desert dust can be transported to there. To present the ADE with higher temporal resolution than available from our samples, hourly $\mathrm{PM}_{10}$ concentrations were combined with meteorological data (Fig. 5a). Times are local except when "UTC" is added.

The $\mathrm{PM}_{10}$ remained normal from 30 April until 12:00 of 5 May, when it increased sharply to a peak of $524 \mu \mathrm{g} \mathrm{m}^{-3}$ within eight hours (Fig. 5a). Over the next $24 \mathrm{~h}$ it decreased (to about $350 \mu \mathrm{g} \mathrm{m}^{-3}$ ), increased (to a little over $400 \mu \mathrm{g} \mathrm{m}^{-3}$ ), and decreased again (to about $200 \mu \mathrm{g} \mathrm{m}^{-3}$ ), after which it returned to $100 \mu \mathrm{g} \mathrm{m}^{-3}$ or so for a few days. Thus the peak lasted less than four hours, and the total event just over $24 \mathrm{~h}$. A similar significant $\mathrm{PM}_{10}$ increase (over an order of magnitude), mainly consisting of desert dust, has also been previously reported during other ADEs (Dillner et al., 2006; Han et al., 2007).

The $24 \mathrm{~h}$ of high dust coincided with $24 \mathrm{~h}$ of low dewpoint and low wind speed. The dewpoint decreased from $18^{\circ} \mathrm{C}$ at noon of 5 May to $12^{\circ} \mathrm{C}$ three hours later. It then climbed back to its previous level through the night and into the next morning, and then decreased to an even lower minimum $\left(9^{\circ} \mathrm{C}\right)$ around $12: 00$ on the next day. Meanwhile, the wind speed was passing through a protracted period of values near zero. The low dewpoints meant that dry air, likely from
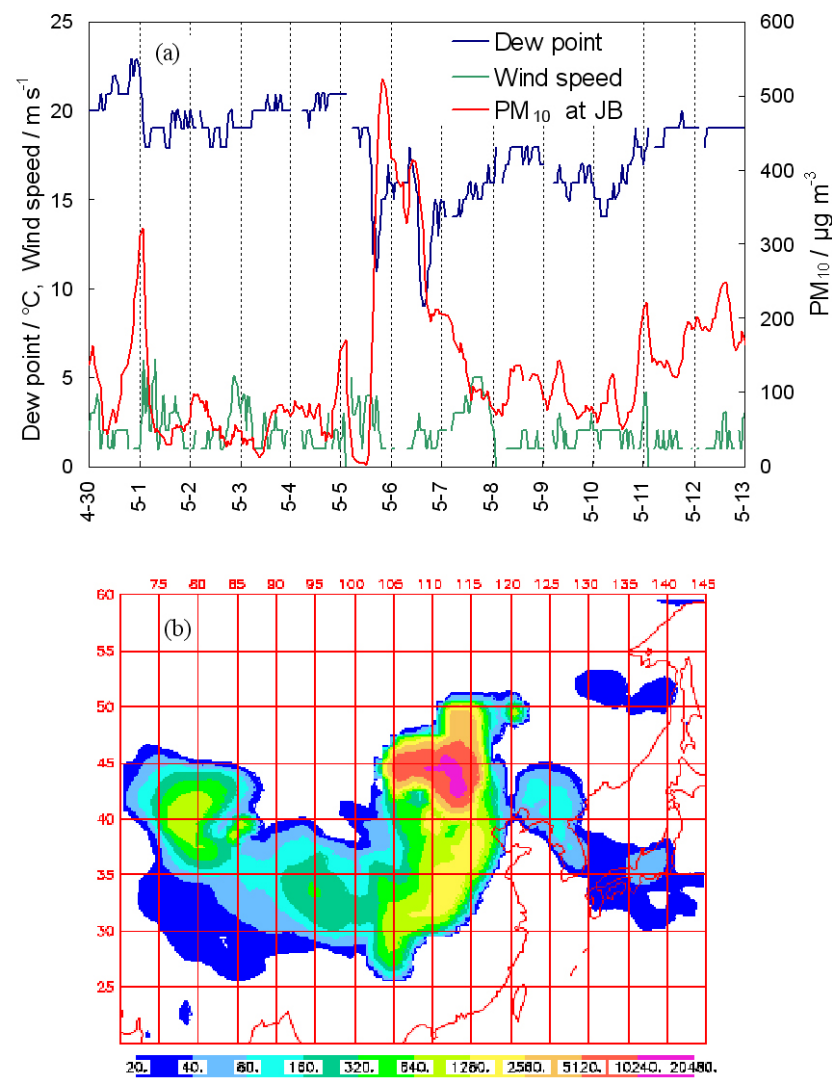

Fig. 5. (a) $\mathrm{PM}_{10}$ (JB site), dewpoint and wind speed at Chongqing from 30 April to 13 May 2005; (b) NAAPS simulated surface dust concentration on local 14:00 (UTC 06:00) 5 May 2005 (unit: $\left.\mu \mathrm{g} \mathrm{m}^{-3}\right)$.

the northwest, arrived along with the enhanced $\mathrm{PM}_{10}$, as has been seen previously for dust storms (Guo et al., 2004). In fact, the first, biggest peak coincided with the first reports of "yellow sky" in Chongqing (Chongqing Times, 2005). The peak and the yellow sky are consistent with a simulation by the NAAPS model (Fig. 5b), which projected that dust covered much of mainland China, including Chongqing, on 14:00 of 5 May.

Afternoon incursions like this are common for dust in China, especially between 18:00 and 21:00 (Wang et al., 2005a). The peak could not have come from local emissions, for at least two reasons: (1) Local fugitive dust (from roads and open fields) would have been a minimum then because the wind speed decreased from $3-4 \mathrm{~m} \mathrm{~s}^{-1}$ to $1 \mathrm{~m} \mathrm{~s}^{-1}$ at the time of the increase; (2) The peak appeared four hours earlier than the normal midnight peak of pollutants, typically caused by reduced dispersion of local emissions during the afternoon and evening. These reasons shift the likely explanation to external factors such as regional pollution or regional desert dust. Regional pollution seems to be ruled out by the fact that all the pollutants decreased while the dust increased (pollutants not shown here). 
Strong evidence that the peak was indeed desert dust comes from our weekly $\mathrm{PM}_{2.5}$ samples. Dust concentrations at all the sites in Chongqing reached their maximum of the whole sampling period during the weeks of 30 April-6 May and 6-13 May (Fig. 4). Sites BB and JB had the greatest dust during the first of those weeks, whereas site DDK had it during the second week. The difference in timing may have been an artifact of the short dust peak and an earlier change of filters at DDK (08:30 on 6 May), two hours earlier than at BB and four hours earlier than at JB. Thus, the brief peak of dust may have been caught on the earlier filters at two sites and the later filter at the third site.

It is not clear why the wind speeds remained low while the dust increased and the dewpoint decreased. The change of dewpoint indicates a change of air, which when from the northwest and dust-laden would normally be energetic. The dust could not have fallen into the lower air because then the dewpoint and the pollution elements would not have changed, as seen before in Beijing (Guo et al., 2004). (Pollution elements discussed below.) The explanation may lie with the terrain near Chongqing. Perhaps the mountains north of Chongqing created mountain waves that brought the dust-laden, dry air from aloft to the surface (McKendry et al., 2001). This pulse of vertical mixing could have been short enough to prevent the event from being recognized as a classical ADE.

\subsection{Constituents in dust and nondust periods}

By using $\mathrm{Al}$ as the indicator of mineral dust, the ratios of other constituents to $\mathrm{Al}$ can be plotted against $\mathrm{Al}$ to try to differentiate the dust of the ADE from aerosols of other periods in Chongqing, and to compare with Beijing, where ADEs have been better characterized.

\subsubsection{Crustal elements: $\mathrm{Si}, \mathrm{Ca}, \mathrm{Mg}$}

$\mathrm{Si} / \mathrm{Al}, \mathrm{Ca} / \mathrm{Al}$, and $\mathrm{Mg} / \mathrm{Al}$ have been plotted against $\mathrm{Al}$, with the 6 samples collected during the major dust weeks being shown in black (Fig. 6). For the samples with lower Al (left side of plot), the ratios were relatively scattered and different for different sites (1.1-4.0, 0.3-2.4 and 0.2-0.6 k respectively), but the strong desert dust and high $\mathrm{Al}$ of the $\mathrm{ADE}$ (right side of plots) brought the ratios closer together at each site and formed a well-defined crustal tail. The average ratios of the $6 \mathrm{ADE}$ sample can be considered as the elemental signatures of the dust: $2.39 \pm 0.11$ for $\mathrm{Si} / \mathrm{Al}, 1.05 \pm 0.11$ for $\mathrm{Ca} / \mathrm{Al}$, and $0.33 \pm 0.02$ for $\mathrm{Mg} / \mathrm{Al}$. Enriched $\mathrm{Ca} / \mathrm{Al}$ is normally used as an indicator of construction dust (Zhang and Iwasaka, 1999), which did not appear during the ADE. As shown in Fig. 6, the $\mathrm{Ca} / \mathrm{Al}$ ratios in the ADE samples were distinguishably lower than those of other periods (1.5-2.4), while the latter was close to the ratios in Beijing's dust (1.53.0) under the influence of construction activities (He et al., 2001).
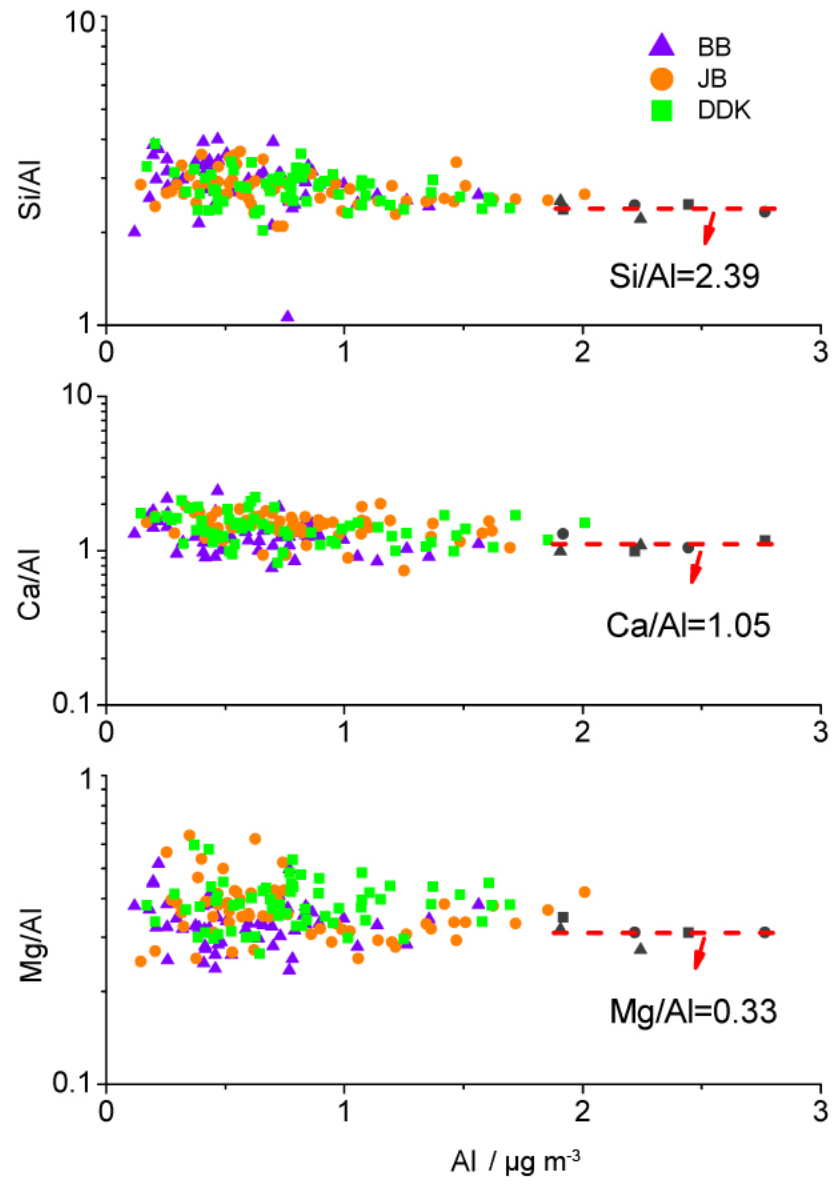

Fig. 6. Scatter plots of $\mathrm{Si} / \mathrm{Al}, \mathrm{Ca} / \mathrm{Al}$ and $\mathrm{Mg} / \mathrm{Al}$ against $\mathrm{Al}$ in $\mathrm{PM}_{2.5}$ at JB, BB and DDK in Chongqing. Black dots in each site represent the ADE weeks in Chongqing on 29 April-6 May and 6-13 May 2005.

To compare with the ADEs in Beijing, we used the week with strongest dust, 7-14 April 2006, when the dust at MY reached $38 \mu \mathrm{g} \mathrm{m}^{-3}$ and the central/eastern Gobi Desert was found to be the dominant source (Sun and Zhao, 2008). Its ratios for $\mathrm{Si} / \mathrm{Al}, \mathrm{Ca} / \mathrm{Al}$ and $\mathrm{Mg} / \mathrm{Al}$ were 2.20, 0.30 and 0.21 , respectively. Although $\mathrm{Si} / \mathrm{Al}$ was similar between the two $\mathrm{ADEs}, \mathrm{Ca} / \mathrm{Al}$ and $\mathrm{Mg} / \mathrm{Al}$ were 3.5 and 1.6 times higher in Chongqing than in Beijing, which strongly suggested that the dusts in the two cities originated from different deserts.

The western Chinese deserts contain abundant minerals that are enriched in $\mathrm{Ca}$ and $\mathrm{Mg}$, such as calcite, dolomite and gypsum (Makra et al., 2002; Li el al., 2007), and so are characterized by higher $\mathrm{Ca}$ and $\mathrm{Mg}$ than the eastern deserts (China National Environmental Monitoring Center, 1994). The high $\mathrm{Ca} / \mathrm{Al}$ and $\mathrm{Mg} / \mathrm{Al}$ of the ADE in Chongqing are very close to the ratios in the western deserts (1.25 and 0.27 , respectively, Nishikawa et al., 1991), whereas for Beijing, $\mathrm{Ca} / \mathrm{Al}$ and $\mathrm{Mg} / \mathrm{Al}$ are more like those of the eastern deserts (0.47-0.78 and 0.16-0.21, respectively, Nishikawa et al., 1991; Liu et al., 2002). This feature has been previously 
reported in other ADE observations either in source regions (Zhang et al., 2003b) or receptor sites such as Beijing, where it was found that $\mathrm{Ca} / \mathrm{Al}$ of the dust from western deserts (1.16) was about 3 times higher than the dust from eastern deserts (0.37) (Yuan et al., 2008). As will be discussed later, back-trajectories also showed that the dust in Chongqing on 5-6 May 2005 came from the western deserts.

The ratios of other crustal elements to Al in ADEs at Chongqing and Beijing appear to be similar to those of bulk soil, as has been found by other studies (Gatz and Prospero, 1996; Holmes and Zoller, 1996; Perry et al., 1997; Prospero et al., 2001; Guo et al., 2004; Cheng et al., 2005). Although $\mathrm{Si} / \mathrm{Al}$ for both events is $30 \%$ lower than in bulk soil (3.83, Taylor and McLennan, 1995), they are quite close to those of transported dust, such as Asian dust in Zhengbeitai (1.9, Arimoto et al., 2004) and Saharan dust over the North Atlantic (2.0-2.3, Chiapello et al., 1997), Italy (2.3, Marenco et al., 2006) and America (2.0, Gatz and Prospero, 1996). This depletion is attributed to the fact that the Si-enriched particles are usually large, and fall out rapidly during transport, which enables low $\mathrm{Si} / \mathrm{Al}$ to be a potential indicator of aged transported dust (Gatz and Prospero, 1996; Negi et al., 2009).

\subsubsection{Pollution derived components: $\mathrm{Pb}, \mathrm{SO}_{4}^{2-}$, and organic carbon}

$\mathrm{Pb}, \mathrm{SO}_{4}^{2-}$, and organic carbon (OC) are generally of pollution origin. Their ratios to $\mathrm{Al}$ decreased significantly as $\mathrm{Al}$ increased, and reached a minimum during the ADE at all three sites in Chongqing (Fig. 7). The same trend is also seen for Beijing, which agrees well with previous studies that ratios of pollution components to $\mathrm{Al}$ in ADEs were expected to be sharply reduced (Rahn, 1979; Guo et al., 2004). Since these species were mainly contributed by the pollution sources such as coal and biomass burning (Duan et al., 2004; Guo et al., 2008; Okuda et al., 2008), the significantly low ratios indicate their minor role in contributing to the high concentrations of mineral dust during these events.

However, since ADEs only last for 1-2 days, pollution aerosols were also collected before and after these events by the weekly samples, which resulted in significant enrichments of pollution components. As for the 6 samples collected during the ADE weeks in Chongqing, organic aerosol $(1.4 \times \mathrm{OC}$, as used in He et al., 2001) and secondary inorganic aerosol $\left(\mathrm{SO}_{4}^{2-}, \mathrm{NO}_{3}^{-}\right.$and $\left.\mathrm{NH}_{4}^{+}\right)$contributed up to $70 \%-80 \%$ of the $\mathrm{PM}_{2.5}$. In contrast to the crustal elements and their stable ratios, $\mathrm{Pb} / \mathrm{Al}, \mathrm{SO}_{4}^{2-} / \mathrm{Al}$, and $\mathrm{OC} / \mathrm{Al}$ varied considerably for the ADE samples in Chongqing, both spatially and temporally. Comparing to the super dust storm at Beijing in 2002, when the ratios of pollution elements to $\mathrm{Al}$ were close to those in bulk soil (Guo et al., 2004), $\mathrm{Pb} / \mathrm{Al}$ during the ADEs in Chongqing (0.09) and Beijing (0.04) of this study were 360 and 160 times higher than the Earth average crust, respectively $(\mathrm{Pb} / \mathrm{Al}=0.00025$, Taylor and McLennan, 1995). However, our observation was not able to show any-
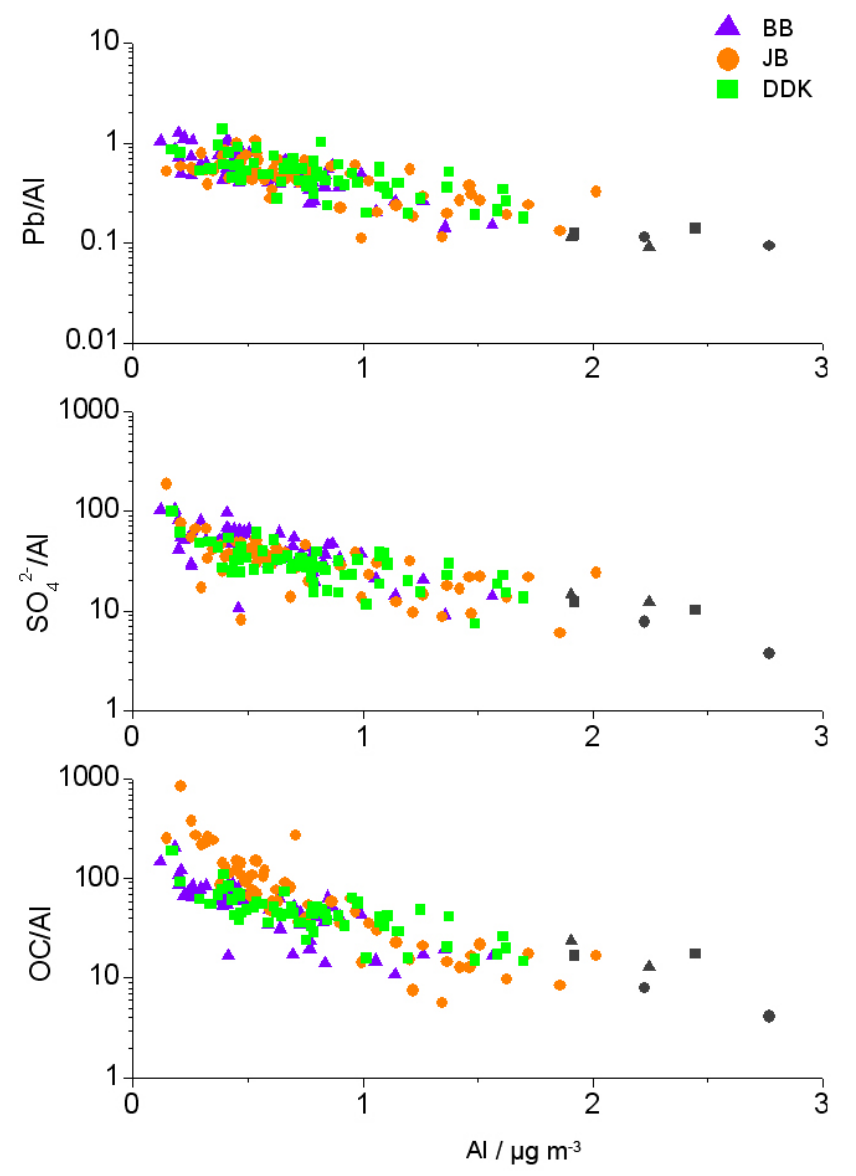

Fig. 7. Scatter plot of $\mathrm{Pb} / \mathrm{Al}, \mathrm{SO}_{4}^{2-} / \mathrm{Al}$, and $\mathrm{OC} / \mathrm{Al}$ against $\mathrm{Al}$ in $\mathrm{PM}_{2.5}$ at JB, BB and DDK in Chongqing. Black dots in each site represent the ADE weeks in Chongqing on 29 April-6 May and 6-13 May 2005.

thing about the mixing of mineral dust with pollution aerosol and the interaction with the gaseous precursors during transport, which are the subjects of future studies related to this work.

\subsection{Transport pathways}

Transport pathways of Asian dust are regulated by meteorology and terrain (Tsai et al., 2008). For most deserts in East Asia, frontal incursions from the northwest accompanied by upper-tropospheric troughs are the dominant mechanism for mobilizing the dust, which can then be carried above or below $3 \mathrm{~km}$ to downwind regions of different distance, depending on the particular synoptic systems present (Sun et al., 2001; Tsai et al., 2008). The Takla Makan Desert in the west is different, however. It is a basin surrounded by high mountains that create circulations within the basin that can keep the dust local for long periods (Tsunematsu et al., 2005), and only occasionally lifted by low-level easterlies to elevations over $5 \mathrm{~km}$ and then transported longer distances (Sun et al., 

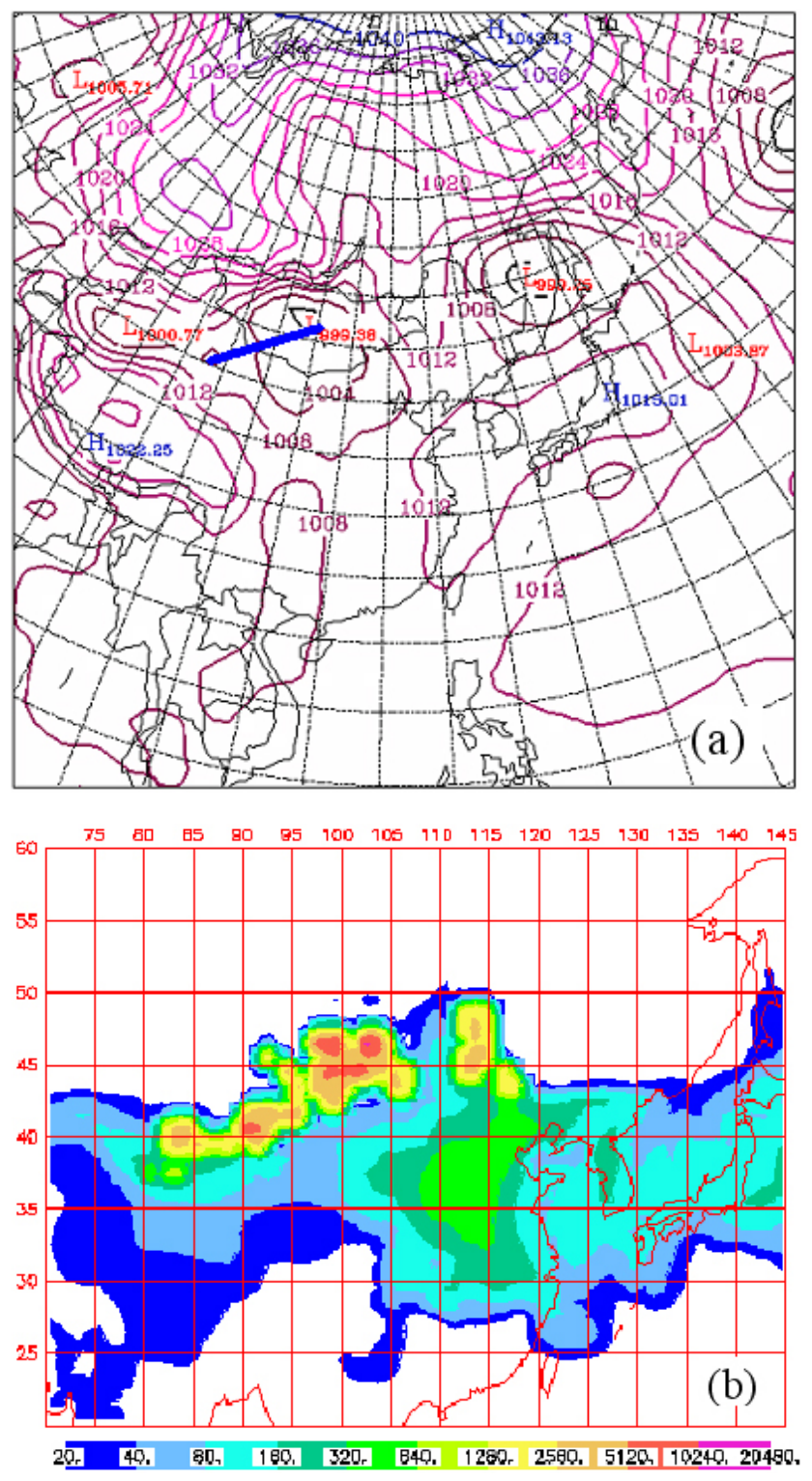

Fig. 8. (a) Mean sea level pressure over China (unit: hPa) on 08:00 (UTC 00:00) 3 May 2005; (b) NAAPS simulated surface dust concentration on 14:00 (UTC 06:00) 3 May 2005 (unit: $\mu \mathrm{g} \mathrm{m}^{-3}$ ). The blue line in (a) represents the location of the cold front.

2001). Synoptic patterns and back-trajectories suggest that both effects were present here.

\subsubsection{Frontal pathway}

During the ADE in Chongqing, the dust transported below $2 \mathrm{~km}$ above ground level (a.g.l., also used for all the heights in the following text) was dominated by frontal lifting. From 30 April 2005, a surface cold front between a high pressure system over Siberia and a low pressure system over Mongolia moved across the Gobi Desert from west to east (Fig. 8a).
As simulated by the NAAPS model, this system provided strong ascending motion for the desert dust and transported it southeastward (Fig. 8b). Back-trajectories showed that these air masses stayed well below $2 \mathrm{~km}$ as they traveled along the border between China and Mongolia and turned southward to Chongqing, and reached heights above $0.6 \mathrm{~km}$ in Chongqing before 03:00 on 6 May (UTC 15:00, 5 May) of 2005. A typical pattern of this pathway arriving at $1 \mathrm{~km}$ a.g.l. in Chongqing is shown in Fig. 9a.

The layer between $0.2 \mathrm{~km}$ and $0.6 \mathrm{~km}$ a.g.l. in Chongqing remained stagnant until 12:00 (UTC 04:00) of 6 May, when its air-mass origins turned abruptly to the remote deserts in the northwest (Fig. 9b). The change of trajectories coincided with the sharp decrease of dewpoint (Fig. 5a), which confirms how a mountain wave may have influenced the vertical air mass exchange between the boundary layer and the dust layer above.

The surface layer below $0.2 \mathrm{~km}$ a.g.l. seemed not to be influenced by the cold front, as the back trajectories from all heights within this layer originated from east or northeast of Chongqing and at low heights (Fig. 9b). Although this phenomenon might be attributed to the low accuracy of the HYSPLIT model when dealing with the complex terrain of Chongqing, it indicates that boundary-layer entrainment could be extensive on the regional scale. At the end of the event, trajectories at all levels below $2 \mathrm{~km}$ a.g.l. in Chongqing returned to the east after 08:00 (UTC 00:00) of 7 May 2005.

In general, the persistent low-level transport of air by the frontal systems here showed the same pattern as one of the dominant Asian dust pathways classified by a recent synoptic study (Tsai et al., 2008). Dust was generated by the surface front between a low and an intense high over the western Gobi desert, and since its location was behind a trough at $700 \mathrm{hPa}$ (not shown), the rising motion was inhibited, and the dust was transported downwind to the near-surface layer under descending or neutral flow conditions (Tsai et al., 2008).

\subsubsection{Terrain-effect pathway}

The higher troposphere over Chongqing was dominated by a different pathway, which originated from the Takla Makan Desert, throughout the ADE in Chongqing. Due to the basins and high mountains in the Takla Makan Desert and the Tibetan Plateau, low- and high-pressure systems began to accumulate over these regions simultaneously from the end of April 2005, and were well established by 3 May (Fig. 8a). As the cold air from the northwest broke into the Takla Makan Desert from its northeastern entrance, it provided strong motion to mobilize the dust. The northeasterly wind was presumed to lift the dust in the Takla Makan Low toward the southwest, but because the northern, western, and southern parts of this region are surrounded by high mountains, the air masses were elevated to around $5 \mathrm{~km}$ a.g.l. and merged into the conveyer belt between the Takla Makan Low and the 

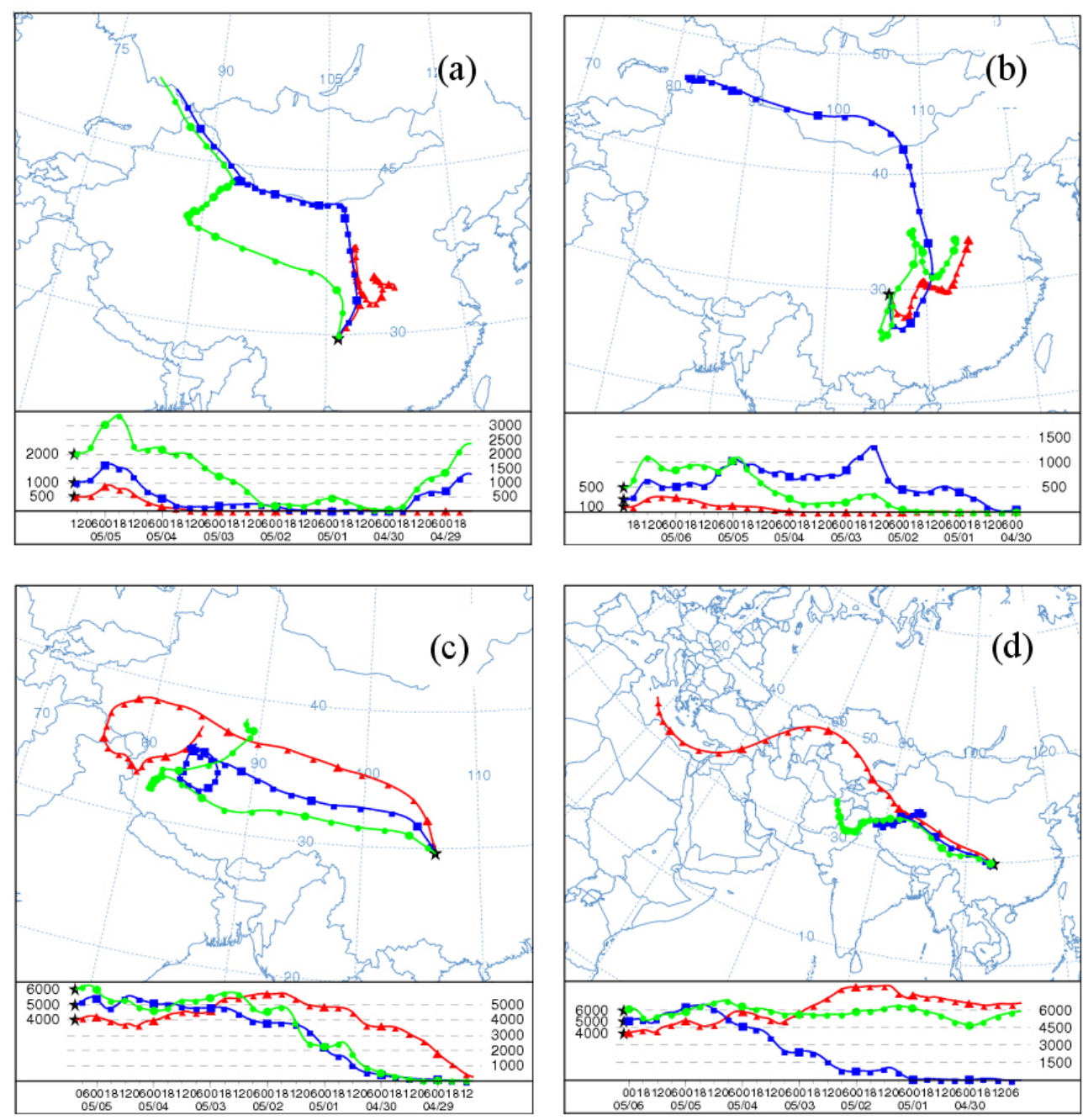

Fig. 9. $168 \mathrm{~h}$ back trajectories at different heights in Chongqing during the ADE. (a) $2 \mathrm{~km}, 1 \mathrm{~km}$ and 0.5 km on 21:00 (UTC 13:00) $5 \mathrm{May}$ 2005; (b) $0.5 \mathrm{~km}, 0.25 \mathrm{~km}$ and 0.1 km on 06:00 7 May (UTC 22:00 6 May) 2005; (c) $6 \mathrm{~km}, 5 \mathrm{~km}$ and 4km on 17:00 (UTC 09:00) $5 \mathrm{May}$ 2005; (d) $6 \mathrm{~km}, 5 \mathrm{~km}, 4 \mathrm{~km}$ on 10:00 (UTC 02:00) 6 May 2005.

Tibetan High, which is clearly indicated by the back trajectories (Fig.9c) and the NAAPS model (Fig. 5b). As a result, the air masses arrived at Chongqing at $6 \mathrm{~km}$ a.g.1. on 15:00 (UTC 07:00) of 5 May, at the same time as the reported dust, the model simulation, and the abrupt change of meteorological conditions previously discussed.

The air masses from the surface of the Takla Makan Desert reached the height exceeding $2 \mathrm{~km}$ in Chongqing by 21:00 (UTC 13:00) of 5 May (Fig. 9a), and this high-level, longrange transport was observed throughout 5-6 May by examining the hourly trajectories at various heights in Chongqing. During this type of transport, the dust from the Takla Makan Desert stayed within a layer around $4-5 \mathrm{~km}$ a.g.l. before arriving at Chongqing (the cases for 10:00 (UTC 02:00) of 6 May 2005 was shown in Fig. 9d), while for the other layers at Chongqing, the air came from the free troposphere above $6 \mathrm{~km}$ far to the west of China. This phenomenon could be ex- plained by the terrain effect lifting the dust rapidly and merging its air quickly into the prevailing westerlies around $5 \mathrm{~km}$ a.g.l., then transporting it within specific layers that could be found as high as $6 \mathrm{~km}$ a.g.l. over the Takla Makan Desert during springtime (Liu et al., 2008).

High-level transport of dust from the Takla Makan was also suggested by Sun et al. (2001), but there are some noteworthy differences between their study and ours. Based on the ADE in Takla Makan on 18-19 May 1986, Sun et al. (2001) reported that the major pathway of dust transport was northwestward at the beginning, then northeastward to latitudes beyond $50^{\circ} \mathrm{N}$. In this study, however, the pathway of the ADE went in the opposite direction, first southwestward and then southeastward to lower latitudes. This is attributed to the different synoptic patterns in the case, as the other one was regulated by a Tibetan Low and a Takla Makan High, opposite to the Tibetan High and Takla Makan Low in 

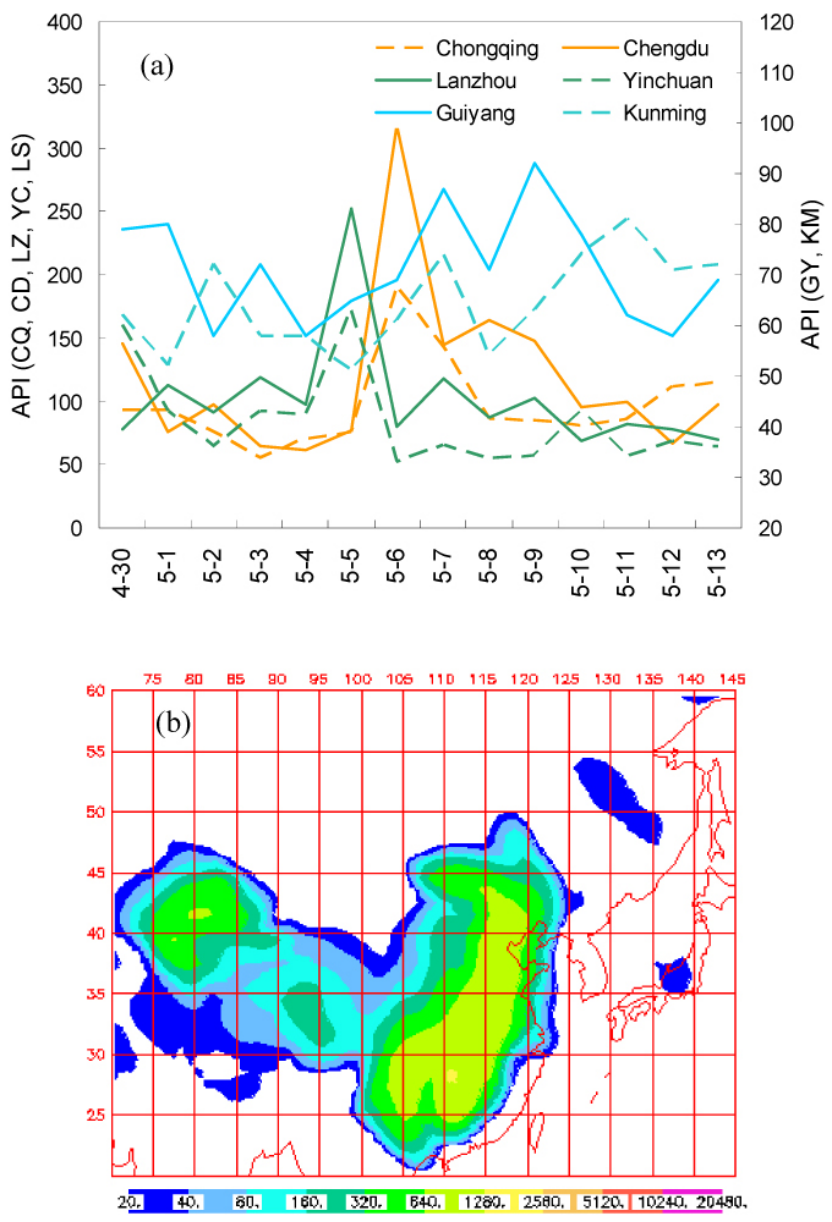

Fig. 10. (a) APIs in selected Chinese cities from 30 April-13 May 2005. The left axis is for Lanzhou (LZ) Yinchuan (YC) in the northwest, and Chongqing (CQ), Chengdu (CD) in the middle west, and the right axis is for Guiyang (GY), Kunming (KM) in the southwest; (b) NAAPS simulated surface dust concentration on 08:00 (UTC 00:00) 6 May 2005 (unit: $\mu \mathrm{g} \mathrm{m}^{-3}$ ).

the Chongqing event. Therefore, the event in Chongqing has possibly provided a new mechanism for upper-level transport from the Takla Makan Desert.

\subsubsection{Pathway verification}

The daily API (Air Pollution Index, data source: http:// datacenter.mep.gov.cn) and NAAPS model results can be used to verify our hypothesis about the transport pathways. As seen in Fig. 10a, peaks of API all with $\mathrm{PM}_{10}$ as the primary pollutant occurred with one day's difference from the northwest (Lanzhou and Yinchuan, 5 May 2005), across the middle west (Chengdu and Chongqing, 6 May 2005), to the southwest (Guiyang and Kunming, 7 May 2005). Its spatial sequence from north to south was consistent with the trajectories, i.e., that air masses from the northwest brought considerable dust to downwind regions. Since dust normally ac- counted for $\sim 40 \%$ of the $\mathrm{PM}_{10}$ mass in Central and Western China (Fang et al., 2009), it is believed to have dominated the $\mathrm{PM}_{10}$ variations during these $\mathrm{ADE}$ periods.

Good agreement also showed up from the model results. As the cold front moved to the southeast, it produced dust or dust storms in a variety of deserts in Northern and Northwestern China, and strong dust plumes swept across the whole country from 3 May to 6 May (Fig. 10b). Eastern deserts (longitude $>105^{\circ} \mathrm{E}$ ) were responsible for the high dust over Eastern and Southeastern China, while western deserts northeast of the Tibetan Plateau (longitude $<105^{\circ} \mathrm{E}$ ) delivered high dust to Central and Southwestern China. Dust from the Takla Makan Desert remained active most of this time, and generally moved eastward or southeastward, but dissipated before it could merge with the larger cloud. This may be partly due to the fact that the NAAPS model only presented the dust concentration at surface level, missing the ascending dust from the Takla Makan.

Although APIs cannot directly represent the dust during this event, and there are uncertainties in the trajectories and the model simulations, their consistency with the chemical and meteorological evidence supports the two pathways from the western deserts to Chongqing. Because the vertical variations of dust could significantly influence the formation of cloud droplets and development of precipitation (Yin and Chen, 2007), our results provide some insights into the potential climatic effect of Asian dust over Central and Southwestern China. More efforts should be made to determine which pathway is more important for this region.

\section{Implications from the rare ADE in Chongqing}

\subsection{Reasons for the scarce ADE reports in Chongqing}

The ADE of 5-6 May 2005 was not the only period that dust in Chongqing reached levels comparable to Beijing. Mineral dust in Chongqing began to increase 1.5 months before the ADE (Fig. 4), and frequent transport of air from the deserts to Chongqing was found throughout the springtime (backtrajectories not shown here).

The national standard (China Meteorological Administration, 2006) divides ADEs into five categories. Three of them are defined as dust storms, when the visibility is less than $1 \mathrm{~km}$ and the winds are strong. The other cases are weaker: Blowing dust and floating dust refer to visibilities of $1-10 \mathrm{~km}$ and $<10 \mathrm{~km}$, respectively, with the only difference between them being that the average wind speed for floating dust should be lower than $3 \mathrm{~m} \mathrm{~s}^{-1}$. These criteria make it necessary to investigate the relationship between the visibility, wind speed, and aerosol species degrading visibility in Chongqing.

During the whole sampling period, $92 \%$ of the days had low visibility $(<10 \mathrm{~km})$ (Fig. 11a). This was partly due to the frequent fog caused by high humidities and strong 


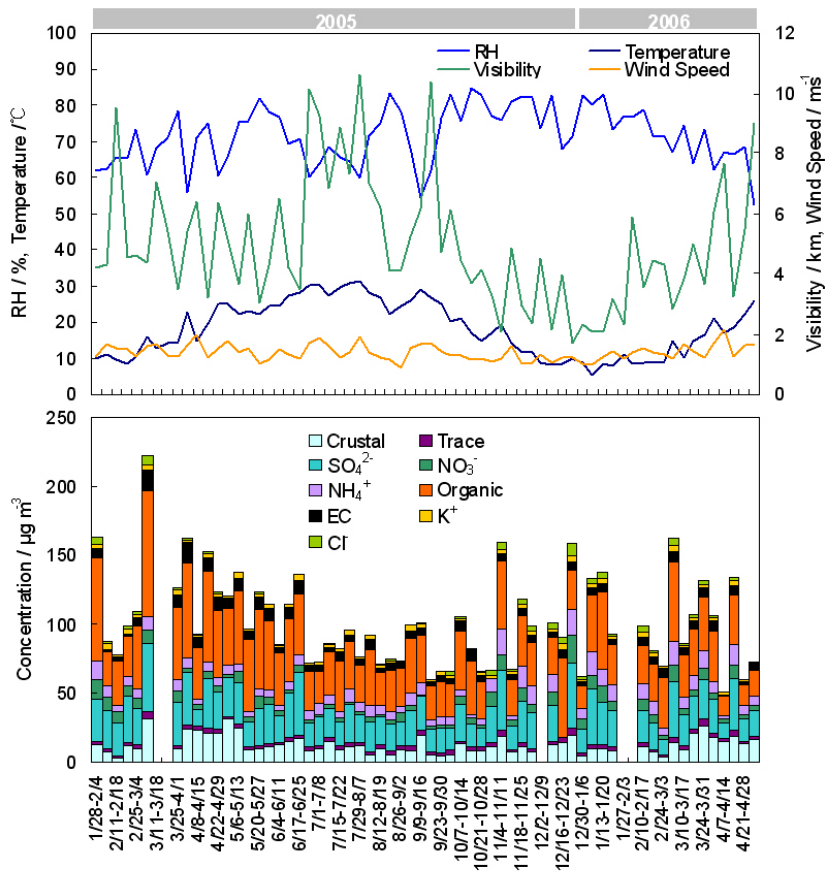

Fig. 11. (a) Weekly meteorological factors in Chongqing including relative humidity, temperature, wind speed and visibility; (b) Chemical composition in $\mathrm{PM}_{2.5}$ in JB from Jan. 2005 to May 2006.

temperature inversions, but the visibility was further degraded by high aerosol. In addition to the strong emission of primary pollutants in Chongqing, production of secondary aerosol was also favored by the low wind speeds (0.9$\left.2.1 \mathrm{~m} \mathrm{~s}^{-1}\right)$, high temperatures $\left(5.3^{\circ} \mathrm{C}-31.3{ }^{\circ} \mathrm{C}\right)$, and humidities (52.3\%-84.9\%) (Fig. 11a). At JB, for instance, organic aerosol $(1.4 \times \mathrm{OC}$, as used in $\mathrm{He}$ et al., 2001) and secondary inorganic aerosol $\left(\mathrm{SO}_{4}^{2-}, \mathrm{NO}_{3}^{-}\right.$, and $\left.\mathrm{NH}_{4}^{+}\right)$contributed up to $70 \%$ of the $\mathrm{PM}_{2.5}$, with ranges of $18 \%-63 \%$ and $21 \%-$ $70 \%$, respectively (Fig. 11b). They also dominated during the ADE, when mineral dust only accounted for $15 \%-20 \%$ of the $\mathrm{PM}_{2.5}$, much less than the pollution-derived species. These conditions could mislead people into thinking that the ADE was a normal pollution event, when it was actually a result of transported desert dust.

High dust loadings over Central and Southwestern China have been shown by satellites and by simulations in recent studies. For instance, lidar measurements from 20062007 showed high dust aerosol during spring (Liu et al., 2008), while for the ADEs of 13-14 April 2001 and 16 April 2006, modeled dust plumes also covered much of this region (McKendry et al., 2008; Tsai et al., 2008). However, no ADEs were reported in Chongqing during those periods. Moreover, the above studies paid much more attention to Northern China and Eastern Asia rather than Central and Southwestern China, and it is reasonable to expect that the presence of Asian dust in Chongqing and its surrounding re- gion has been strongly underestimated during springtime. In respect of its possible influence on the violation of China's National Ambient Air Quality Standard, which is for $\mathrm{PM}_{10}$ rather than $\mathrm{PM}_{2.5}$, previous studies have shown that coarse particles of Asian desert dust $\left(\mathrm{PM}_{2.5-10}\right)$ still dominated up to $60 \%-80 \%$ of $\mathrm{PM}_{10}$ after the long range transport (over 1000-2000 km, Mori et al., 2003; Cheng et al., 2005). Therefore, significant increase of dust in all size range of $\mathrm{PM}_{10}$ during the ADEs in Chongqing would also be expected, although our study has provided evidence mainly for the fine dust.

\subsection{Underestimation of Asian dust in the cold season}

Our results from Chongqing indicate that transported Asian dust can be abundant even without reported ADEs. The relation between observations and model results suggests that transported dust could also be abundant during the cold season, although few ADEs have been reported in receptor regions such as Beijing.

A rare ADE in fall (5-7 November 2005) spread over Northern China (Ministry of Environmental Protection of China, 2006). It caused a dust peak in Beijing during the week of 4-11 November 2005, as predicted (MY: $11.2 \mu \mathrm{g} \mathrm{m}^{-3}$, Fig. 4), and was well reproduced by the NAAPS model (Fig. 12a). However, the other weekly peaks of dust, 14-21 October, 25 November-2 December, 23-30 December 2005, 13-20 January, and 17-24 February 2006 (Fig. 4), were responding to dust emissions over the eastern deserts on 14-16 October, 28 November, 22-23 December 2005, 14 January and 19-21 February 2006, respectively, which were well reproduced by the model but not called ADEs (Fig. 12b shows the peak for 28 November). It seems that as the dust plumes moved across Beijing toward Southeastern China, they created the dusty weeks in Beijing. Similar dust concentrations also appeared during the same periods in Chongqing (7-14 October, 4-11 November, and 2330 December 2005; and 17-24 February 2006; Fig. 4), but most of them were not predicted by the model. Thus it is still not clear whether these high peaks in Chongqing were from remote deserts. Improved dust simulations will eventually provide the answer, we hope.

Frequent incursions of Asian dust during winter have been found over other regions, from Southeastern China (Wang et al., 2005a; Liu et al., 2008) to North America (VanCuren and Cahill, 2002). Along with this study, they support the idea that ADE reports can underrepresent large areas of dust activity (Prospero et al., 2002), which makes them unreliable indicators for evaluating the regional influence of Asian dust. Because meteorological stations are normally located at reachable sites such as urban areas or agricultural lands, there can be other days when ADEs are present in remote regions but go unreported. Fine-mode Asian dust that has retained high concentrations even after long range transport could still contribute much to aerosol at remote sites without 

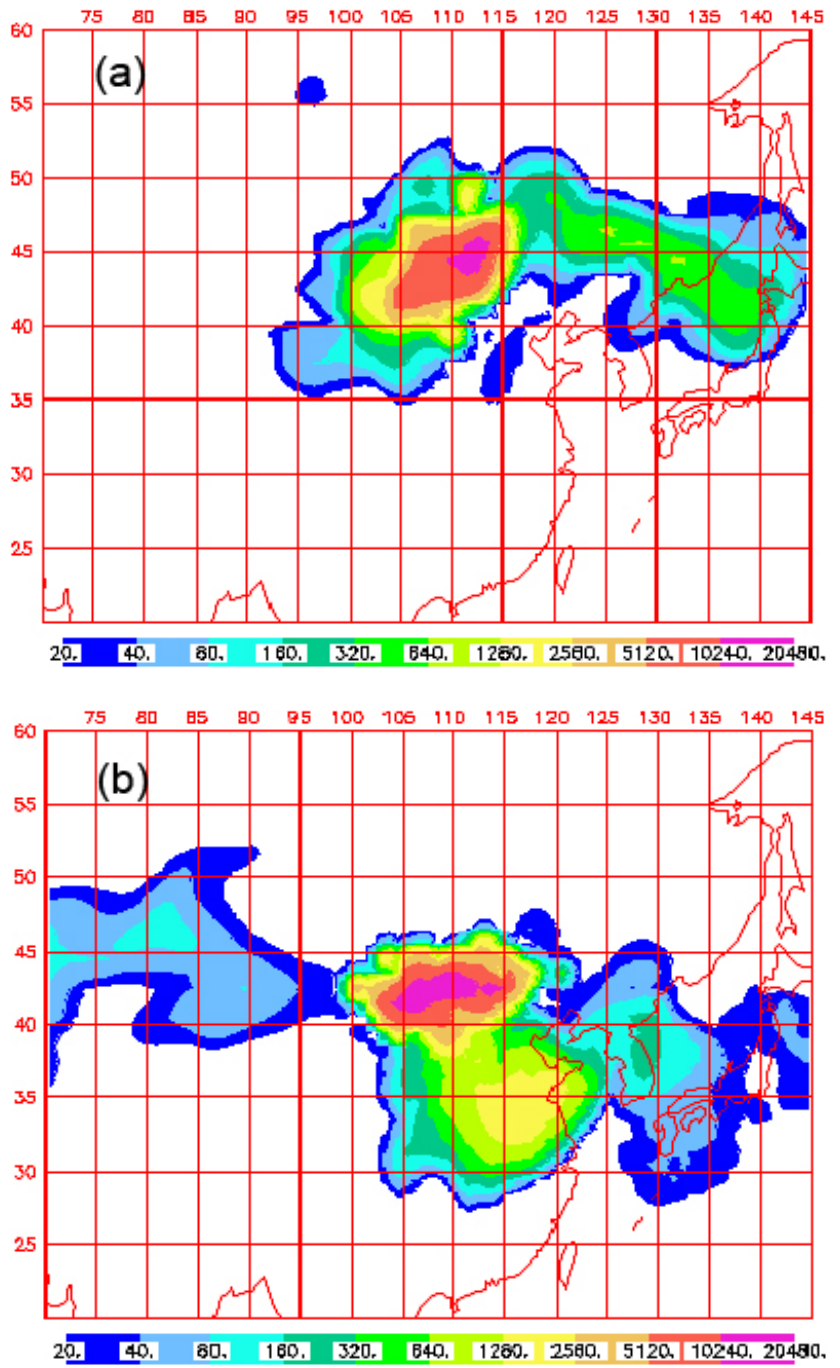

Fig. 12. NAAPS simulated surface dust concentration on (a) UTC 00:00, 5 November 2005 and (b) UTC 06:00, 28 November 2005 (Unit: $\mu \mathrm{g} \mathrm{m}^{-3}$ ).

meeting the ADE criteria, and affect atmospheric processes by providing a surface for heterogeneous reactions to occur on (Usher et al., 2003).

\section{Summary and conclusions}

1. The annual $\mathrm{PM}_{2.5}$ concentration was higher and more evenly distributed at Chongqing than at Beijing. The same was true for mineral dust, which was conservatively estimated from the oxides of nine major crustal elements. As at Beijing, dust in Chongqing was highest in spring, lowest in summer, and intermediate during fall and winter, with extensive fluctuations. During springtime, dust concentrations were significantly correlated both within Chongqing and between Chongqing and Beijing (correlation coefficients of 0.62 and 0.55 for urban sites and rural sites, respectively). This suggests the Asian desert dusts are influencing air quality in China over broad regions of China.

2. The rare ADE in Chongqing during 5-6 May 2005 provided a valuable opportunity to investigate the regional transport of Asian dust in this region. Dust concentrations were higher in Chongqing $\left(20-30 \mu \mathrm{g} \mathrm{m}^{-3} ; 15 \%-20 \%\right.$ of $\mathrm{PM}_{2.5}$ ) than at the same time in Beijing $\left(15 \mu \mathrm{g} \mathrm{m}^{-3} ; 20 \%-30 \%\right.$ of $\mathrm{PM}_{2.5}$ ). The proportions of crustal elements during the ADE in Chongqing were relatively uniform and comparable to that of bulk soil, and the same applies to comparatively strong ADEs in Beijing. The dust in Chongqing was considerably enriched in $\mathrm{Ca}$ and $\mathrm{Mg}$, characteristic of western deserts, whereas the dust in Beijing had lower $\mathrm{Ca}$ and $\mathrm{Mg}$, characteristic of eastern deserts. Ratios to $\mathrm{Al}$ of pollution-derived components, such as $\mathrm{Pb}, \mathrm{SO}_{4}^{2-}$, and $\mathrm{OC}$, decreased significantly as $\mathrm{Al}$ concentration increased, indicating that anthropogenic sources played a minor role in the contribution of high dust loading during the ADE in Chongqing.

3. Synoptic patterns and back-trajectories confirm the dominance of western deserts for the ADE in Chongqing, and suggest two transport pathways, for different altitudes. The frontal pathway was traced to the western Gobi Desert, where dust was lifted by the cold front and constrained below $2 \mathrm{~km}$ above ground level. The terrain-effect pathway dominated transport above $2 \mathrm{~km}$, and generally originated from the Takla Makan Desert under the topographic influence of its basin and the surrounding mountains.

4. The chemical composition, combined with meteorology and the NAAPS model simulations, suggested that during springtime, the influence of transported Asian dust in Chongqing, or even at a regional scale in Central and Southwestern China, was considerably underestimated. Due to the limited data on aerosol composition in Chongqing, the low wind speeds and high organic and secondary aerosols can easily mislead people into thinking that ADEs are actually normal pollution events. Something similar applies to northern places like Beijing, in that Asian dust may be abundant during the cold season even if dust events are not being reported.

In summary, regional transport of desert dust from the Gobi and the Takla Makan Deserts can significantly affect air quality and chemical composition of aerosol in Central and Southwestern China, even when dust is not officially reported. This dust may also affect wet and dry deposition, public health, and climate. All these topics need further investigation. Since dust episodes are natural events, their effects should be carefully considered when developing and promulgating China's National Ambient Air Quality Standard.

Acknowledgements. This research was supported by the National Natural Science Foundation of China 20625722 (Carbonaceous species and complex mechanism of particulate air pollution). We thank Shi Zongbo and the staff of the Chongqing Research 
Academy of Environmental Sciences for collecting the aerosol samples in Chongqing. We thank Tai Chan for valuable suggestions in revising the manuscript. We also gratefully acknowledge the NOAA Air Resources Laboratory (ARL) for provision of the HYSPLIT trajectory model and meteorological data, and US Naval Research Laboratory (NRL) for sharing the result of global dust simulation for public use.

Edited by: A. Pszenny

\section{References}

Arimoto, R., Duce, R. A., Savoie, D. L., Prospero, J. M., Talbot, R., Cullen, J. D., Tomza, U., Lewis, N. F., and Jay, B. J.: Relationships among aerosol constituents from Asia and the North Pacific during PEM-West A, J. Geophys. Res.-Atmos., 101, 2011-2023, 1996.

Arimoto, R., Zhang, X. Y., Huebert, B. J., Kang, C. H., Savoie, D. L., Prospero, J. M., Sage, S. K., Schloesslin, C. A., Khaing, H. M., and Oh, S. N.: Chemical composition of atmospheric aerosols from Zhenbeitai, China, and Gosan, South Korea, during ACE-Asia, J. Geophys. Res.-Atmos., 109, D19S04, doi:10.1029/2003jd004323, 2004.

Beijing Municipal Bureau of Statistics: Beijing statistical Yearbook (in Chinese), available online at: http://www.bjstats.gov.cn/tjnj/ 2008-tjnj, 2008.

Bory, A. J. M., Biscaye, P. E., Svensson, A., and Grousset, F. E.: Seasonal variability in the origin of recent atmospheric mineral dust at North GRIP, Greenland, Earth Planet Sci. Lett., 196, 123134, 2002.

Cachier, H. and Ducret, J.: Influence of biomass burning on equatorial african rains, Nature, 352, 228-230, 1991.

Chan, C. K., and Yao, X.: Air pollution in mega cities in China, Atmos. Environ., 42, 1-42, 2008.

Cheng, M. T., Lin, Y. C., Chio, C. P., Wang, C. F., and Kuo, C. Y.: Characteristics of aerosols collected in central Taiwan during an Asian dust event in spring 2000, Chemosphere, 61, 1439-1450, 2005.

Chiapello, I., Bergametti, G., Chatenet, B., Bousquet, P., Dulac, F., and Soares, E. S.: Origins of African dust transported over the northeastern tropical Atlantic, J. Geophys. Res.-Atmos., 102, 13701-13709, 1997.

China Meteorological Administration: Grade of sand dust storm weather (GB/T 20480-2006) (in Chinese), Standards Press of China, Beijing, China, 20-23, 2006.

China National Environmental Monitoring Center: The atlas of soil environmental background value in the People's Republic of China, China Environmental Science Press, Beijing, China, 75-76, 1994.

Chongqing Times: http://cqsb.hsw.cn/gb/cqsb/2005-05/07/content_ 1857020.htm, (in Chinese), 2005.

Chongqing Municipal Bureau of Statistics: Chongqing statistical Yearbook (in Chinese), http://www.cqtj.gov.cn/tjnj/2006/, 2006.

Chongqing Municipal Bureau of Statistics: Chongqing statistical Yearbook (in Chinese), http://www.cqtj.gov.cn/tjnj/2008/, 2008.

Cohen, D. D., Garton, D., Stelcer, E., Hawas, O., Wang, T., Poon, S., Kim, J., Choi, B. C., Oh, S. N., Shin, H. J., Ko, M. Y., and Uematsu, M.: Multielemental analysis and characterization of fine aerosols at several key ACE-Asia sites, J. Geophys. Res.Atmos., 109, 18, D19S12, doi:10.1029/2003jd003569, 2004.

Dentener, F. J., Carmichael, G. R., Zhang, Y., Lelieveld, J., and Crutzen, P. J.: Role of mineral aerosol as a reactive surface in the global troposphere, J. Geophys. Res.-Atmos., 101, 2286922889, 1996.

Dillner, A. M., Schauer, J. J., Zhang, Y. H., Zeng, L. M., and Cass, G. R.: Size-resolved particulate matter composition in Beijing during pollution and dust events, J. Geophys. Res.-Atmos., 111, D05203, doi:10.1029/2005jd006400, 2006.

Duan, F. K., Liu, X. D., Yu, T., and Cachier, H.: Identification and estimate of biomass burning contribution to the urban aerosol organic carbon concentrations in Beijing, Atmos. Environ., 38, 1275-1282, 2004.

Fang, M., Chan, C. K., and Yao, X. H.: Managing air quality in a rapidly developing nation: China, Atmos. Environ., 43, 79-86, 2009.

Fu, F. F., Watanabe, K., Yabuki, S., and Akagi, T.: Seasonal characteristics of chemical compositions of the atmospheric aerosols collected in urban seaside area at Tokaimura, eastern central Japan, J. Geophys. Res.-Atmos., 109, D20212, doi:10.1029/2004jd004712, 2004.

Gao, Y., Nelson, E. D., Field, M. P., Ding, Q., Li, H., Sherrell, R. M., Gigliotti, C. L., Van Ry, D. A., Glenn, T. R., and Eisenreich, S. J.: Characterization of atmospheric trace elements on $\mathrm{PM}_{2.5}$ particulate matter over the New York-New Jersey harbor estuary, Atmos. Environ., 36, 1077-1086, 2002.

Gatz, D. F. and Prospero, J. M.: A large silicon-aluminum aerosol plume in central Illinois: North African desert dust?, Atmos. Environ., 30, 3789-3799, 1996.

Guo, J., Rahn, K. A., and Zhuang, G. S.: A mechanism for the increase of pollution elements in dust storms in Beijing, Atmos. Environ., 38, 855-862, 2004.

Guo, X., Chen, D., and Zheng, C. G.: Experimental study on emission characteristics of $\mathrm{PM}_{10}$-fraction in coal-fired boilers, AsiaPacific J. Chem. Eng., 3, 514-520, 2008.

Han, L. H., Zhuang, G. S., Cheng, S. Y., and Li, J.: The mineral aerosol and its impact on urban pollution aerosols over Beijing, China, Atmos. Environ., 41, 7533-7546, 2007.

He, K. B., Yang, F. M., Ma, Y. L., Zhang, Q., Yao, X. H., Chan, C. K., Cadle, S., Chan, T., and Mulawa, P.: The characteristics of PM2.5 in Beijing, China, Atmos. Environ., 35, 4959-4970, 2001.

Holmes, J. and Zoller, W.: The elemental signature of transported Asian dust at Mauna Loa observatory, Tellus B, 48, 83-92, 1996.

Husar, R. B., Tratt, D. M., Schichtel, B. A., Falke, S. R., Li, F., Jaffe, D., Gasso, S., Gill, T., Laulainen, N. S., Lu, F., Reheis, M. C., Chun, Y., Westphal, D., Holben, B. N., Gueymard, C., McKendry, I., Kuring, N., Feldman, G. C., McClain, C., Frouin, R. J., Merrill, J., DuBois, D., Vignola, F., Murayama, T., Nickovic, S., Wilson, W. E., Sassen, K., Sugimoto, N., and Malm, W. C.: Asian dust events of April 1998, J. Geophys. Res.-Atmos., 106, 18317-18330, 2001.

Intergovernmental Panel on Climate Change (IPCC), Climate Change 2001: The Scientific Basis-Contribution of Working Group I to the Third Assessment Report of the Intergovernmental Panel on Climate Change, Cambridge Univ. Press, New York, USA, available online at: http://www.grida.no/publications/other/ipcc_tar/?src=/climate/ 
ipcc_tar/wg1/015.htm\#figTechSum9, 2001.

Jia, Y. T., Rahn, K. A., He, K. B., Wen, T. X., and Wang, Y. S.: A novel technique for quantifying the regional component of urban aerosol solely from its sawtooth cycles, J. Geophys. Res.-Atmos., 113(16), D21309, doi:10.1029/2008jd010389, 2008.

Kim, Y. K., Song, S. K., Lee, H. W., Kim, C. H., Oh, I. B., Moon, Y. S., and Shon, Z. H.: Characteristics of Asian dust transport based on synoptic meteorological analysis over Korea, J. Air Waste Manage., 56, 306-316, 2006.

Larssen, T., Schnoor, J. L., Seip, H. M., and Dawei, Z.: Evaluation of different approaches for modeling effects of acid rain on soils in China, Sci. Total Environ., 246, 175-193, 2000.

Larssen, T., Seip, H. M., Carmichael, G. R., and Schnoor, J. L.: The importance of calcium deposition in assessing impacts of acid deposition in China, Water Air Soil Pollut., 130, 1635-1640, 2001.

Laurent, B., Marticorena, B., Bergametti, G., Chazette, P., Maignan, F., and Schmechtig, C.: Simulation of the mineral dust emission frequencies from desert areas of China and Mongolia using an aerodynamic roughness length map derived from the POLDER/ADEOS 1 surface products, J. Geophys. Res.-Atmos., 110(21), D18S04, doi:10.1029/2004jd005013, 2005.

Li, G., Chen, J., Chen, Y., Yang, J., Ji, J., and Liu, L.: Dolomite as a tracer for the source regions of Asian dust, J. Geophys. Res.Atmos., 112, D17201, doi:10.1029/2007jd008676, 2007.

Li, W. J. and Shao, L. Y.: Observation of nitrate coatings on atmospheric mineral dust particles, Atmos. Chem. Phys., 9, 18631871, 2009, http://www.atmos-chem-phys.net/9/1863/2009/.

Liu, C. L., Zhang, J., and Shen, Z. B.: Spatial and temporal variability of trace metals in aerosol from the desert region of China and the Yellow Sea, J. Geophys. Res.-Atmos., 107(D14), 4215, doi:10.1029/2001jd000635, 2002a.

Liu, C., Zhang, J., and Liu, S.: Physical and chemical characters of materials from several mineral aerosol sources in China. Environmental Science, 23, 28-32 (in Chinese with abstract in English), 2002b.

Liu, D., Wang, Z., Liu, Z. Y., Winker, D., and Trepte, C.: A height resolved global view of dust aerosols from the first year CALIPSO lidar measurements, J. Geophys. Res.-Atmos., 113, doi:10.1029/2007jd009776, 2008.

Makra, L., Borbely-Kiss, I., Koltay, E., and Chen, Y.: Enrichment of desert soil elements in Takla Makan dust aerosol, Nucl. Instrum. Meth. B, 189, 214-220, 2002.

Marenco, F., Bonasoni, P., Calzolari, F., Ceriani, M., Chiari, M., Cristofanelli, P., D'Alessandro, A., Fermo, P., Lucarelli, F., Mazzei, F., Nava, S., Piazzalunga, A., Prati, P., Valli, G., and Vecchi, R.: Characterization of atmospheric aerosols at Monte Cimone, Italy, during summer 2004: Source apportionment and transport mechanisms, J. Geophys. Res.-Atmos., 111, D24202, doi:10.1029/2006jd007145, 2006.

McKendry, I. G., Hacker, J. P., Stull, R., Sakiyama, S., Mignacca, D., and Reid, K.: Long-range transport of Asian dust to the Lower Fraser Valley, British Columbia, Canada, J. Geophys. Res.-Atmos., 106, 18361-18370, 2001.

McKendry, I. G., Macdonald, A. M., Leaitch, W. R., van Donkelaar, A., Zhang, Q., Duck, T., and Martin, R. V.: Trans-Pacific dust events observed at Whistler, British Columbia during INTEX-B, Atmos. Chem. Phys., 8, 6297-6307, 2008, http://www.atmos-chem-phys.net/8/6297/2008/.
Ministry of Environmental Protection of China: Report on the State of Environment in China (in Chinese). http://www.sepa.gov.cn/ plan/zkgb/06hjzkgb/, 2006

Mori, I., Nishikawa, M., Quan, H., and Morita, M.: Estimation of the concentration and chemical composition of kosa aerosols at their origin, Atmos. Environ., 36, 4569-4575, 2002.

Mori, I., Nishikawa, M., Tanimura, T., and Quan, H.: Change in size distribution and chemical composition of kosa (Asian dust) aerosol during long-range transport, Atmos. Environ., 37, 42534263, 2003.

National Bureau of Statistics of China: China energy statistical Yearbook (in Chinese). China Statistics Press, Beijing, China, 2007.

Negi, B. S., Jha, S. K., Chavan, S. B., Sadasivan, S., Goyal, A., Sapru, M. L., and Bhat, C. L.: Atmospheric dust loads and their elemental composition at a background site in India, Environmental Monitoring and Assessment, 73, 1-6, 2002.

Nishikawa, M., Kanamori, S., Kanamori, N., and Mizoguchi, T.: Kosa aerosol as eolian carrier of anthropogenic Material, Sci. Total Environ., 107, 13-27, 1991.

Okuda, T., Katsuno, M., Naoi, D., Nakao, S., Tanaka, S., He, K. B., Ma, Y. L., Lei, Y., and Jia, Y. T.: Trends in hazardous trace metal concentrations in aerosols collected in Beijing, China from 2001 to 2006, Chemosphere, 72, 917-924, 2008.

Perry, K. D., Cahill, T. A., Eldred, R. A., Dutcher, D. D., and Gill, T. E.: Long-range transport of North African dust to the eastern United States, J. Geophys. Res.-Atmos., 102, 11225-11238, 1997.

Prospero, J. M., Olmez, I., and Ames, M.: Al and Fe in $\mathrm{PM}_{2.5}$ and $\mathrm{PM}_{10}$ suspended particles in south-central Florida: The impact of the long range transport of African mineral dust, Water Air Soil Pollut., 125, 291-317, 2001.

Prospero, J. M., Ginoux, P., Torres, O., Nicholson, S. E., and Gill, T. E.: Environmental characterization of global sources of atmospheric soil dust identified with the Nimbus 7 Total Ozone Mapping Spectrometer (TOMS) absorbing aerosol product, Rev. Geophys., 40(31), 1002, doi:10.1029/2000rg000095, 2002.

Querol, X., Viana, M., Alastuey, A., Amato, F., Moreno, T., Castillo, S., Pey, J., de la Rosa, J., de la Campa, A. S., Artinano, B., Salvador, P., Dos Santos, S. G., Fernandez-Patier, R., Moreno-Grau, S., Negral, L., Minguillon, M. C., Monfort, E., Gil, J. I., Inza, A., Ortega, L. A., Santamaria, J. M., and Zabalza, J.: Source origin of trace elements in PM from regional background, urban and industrial sites of Spain, Atmos. Environ., 41, 7219-7231, 2007.

Rahn, K. A.: Silicon and aluminum in atmospheric aerosols - Crustair fractionation, Atmos. Environ., 10, 597-601, 1976.

Rahn, K. A., Borys, R. D., Shaw, G. E., Schutz, L. and Jaenicke, R.: Long Range Impact of Desert Aerosol on Atmospheric Chemistry: Two Examples, in: Saharan Dust: Mobilization, Transport and Deposition, edited by: Morales, C., SCOPE, John Wiley \& Sons, Chichester, 14, 243-266, 1979.

Sun, J. H. and Zhao, L. N.: Numerical simulation of two East Asian dust storms in spring 2006, Earth Surf. Process. Landf., 33, 1892-1911, 2008.

Sun, J. M., Zhang, M. Y., and Liu, T. S.: Spatial and temporal characteristics of dust storms in China and its surrounding regions, 1960-1999: Relations to source area and climate, J. Geophys. Res.-Atmos., 106, 10325-10333, 2001. 
Sun, Y. L., Zhuang, G. S., Ying, W., Han, L. H., Guo, J. H., Mo, D., Zhang, W. J., Wang, Z. F., and Hao, Z. P.: The air-borne particulate pollution in Beijing - concentration, composition, distribution and sources, Atmos. Environ., 38, 5991-6004, 2004.

Sullivan, R. C., Guazzotti, S. A., Sodeman, D. A., and Prather, K. A.: Direct observations of the atmospheric processing of Asian mineral dust, Atmos. Chem. Phys., 7, 1213-1236, 2007, http://www.atmos-chem-phys.net/7/1213/2007/.

Taylor, S. R. and McLennan, S. M.: The geochemical evolution of the continental-crust, Rev. Geophys., 33, 241-265, 1995.

Tsai, F., Chen, G. T. J., Liu, T. H., Lin, W. D., and Tu, J. Y.: Characterizing the transport pathways of Asian dust, J. Geophys. Res.Atmos., 113, D17311, doi:10.1029/2007jd009674, 2008.

Tsunematsu, N., Kai, K., and Matsumoto, T.: The Influence of synoptic-scale air flow and local circulation on the dust layer height in the north of the Taklimakan Desert, Water Air Soil Pollut., Focus, 5, 175-193, 2005.

Uematsu, M., Duce, R. A., Prospero, J. M., Chen, L., Merrill, J. T., and McDonald, R. L.: Transport of mineral aerosol from Asia over the North Pacific-ocean, J. Geophys. Res -Oceans and Atmos., 88, 5343-5352, 1983.

Usher, C. R., Michel, A. E., and Grassian, V. H.: Reactions on mineral dust, Chemical Reviews, 103, 4883-4939, 2003.

VanCuren, R. A. and Cahill, T. A.: Asian aerosols in North America: Frequency and concentration of fine dust, J. Geophys. Res.Atmos., 107(16), 4804, doi:10.1029/2002jd002204, 2002.

Wai, K. M. and Tanner, P. A.: Case studies of Asian dust storm impacts on a coastal site: Implication of a good dust storm tracer, Water Air Soil Pollut., 168, 59-70, 2005.

Wang, S. G., Wang, J. Y., Zhou, Z. J., and Shang, K. Z.: Regional characteristics of three kinds of dust storm events in China, Atmos. Environ., 39, 509-520, 2005a.

Wang, Y., Zhuang, G. S., Tang, A. H., Yuan, H., Sun, Y. L., Chen, S. A., and Zheng, A. H.: The ion chemistry and the source of PM2.5 aerosol in Beijing, Atmos. Environ., 39, 3771-3784, 2005b.

Wang, Y., Zhuang, G. S., Tang, A. H., Zhang, W. J., Sun, Y. L., Wang, Z. F., and An, Z. S.: The evolution of chemical components of aerosols at five monitoring sites of China during dust storms, Atmos. Environ., 41, 1091-1106, 2007.
Wei, F., Teng, E., Wu, G., Hu, W., Wilson, W. E., Chapman, R. S., Pau, J. C., and Zhang, J.: Ambient concentrations and elemental compositions of PM10 and $\mathrm{PM}_{2.5}$ in four Chinese cities, Environ. Sci. Technol., 33, 4188-4193, 1999.

Yin, Y., and Chen, L.: The effects of heating by transported dust layers on cloud and precipitation: a numerical study, Atmos. Chem. Phys., 7, 3497-3505, 2007, http://www.atmos-chem-phys.net/7/3497/2007/.

Yuan, H., Zhuang, G. S., Li, J., and Wang, Z. F.: Mixing of mineral with pollution aerosols in dust season in Beijing: Revealed by source apportionment study, Atmos. Environ., 42, 2141-2157, 2008.

Zhang, D. Z. and Iwasaka, Y.: Nitrate and sulfate in individual Asian dust-storm particles in Beijing, China in spring of 1995 and 1996, Atmos. Environ., 33, 3213-3223, 1999.

Zhang, X. Y., Arimoto, R., Cao, J. J., An, Z. S., and Wang, D.: Atmospheric dust aerosol over the Tibetan Plateau, J. Geophys. Res.-Atmos., 106, 18471-18476, 2001.

Zhang, X. Y., Gong, S. L., Arimoto, R., Shen, Z. X., Mei, F. M., Wang, D., and Cheng, Y.: Characterization and temporal variation of Asian dust aerosol from a site in the northern Chinese deserts, J. Atmos. Chem., 44, 241-257, 2003a.

Zhang, X. Y., Gong, S. L., Shen, Z. X., Mei, F. M., Xi, X. X., Liu, L. C., Zhou, Z. J., Wang, D., Wang, Y. Q., and Cheng, Y.: Characterization of soil dust aerosol in China and its transport and distribution during 2001 ACE-Asia: 1. Network observations, J. Geophys. Res.-Atmos., 108(13), 4261, doi:10.1029/2002jd002632, 2003b.

Zhang, X. Y., Wang, Y. Q., Zhang, X. C., Guo, W., Niu, T., Gong, S. L., Yin, Y., Zhao, P., Jin, J. L., and Yu, M.: Aerosol monitoring at multiple locations in China: contributions of EC and dust to aerosol light absorption, Tellus B, 60, 647-656, 2008. 